\title{
Adverse Drug Reactions of Acetylcholinesterase Inhibitors in Older People Living with Dementia: A Comprehensive Literature Review
}

\author{
Sirasa Ruangritchankul (D) \\ Prawat Chantharit (D) ${ }^{2}$ \\ Sahaphume Srisuma iD ${ }^{3}$ \\ Leonard C Gray (iD) 4 \\ 'Division of Geriatric Medicine, \\ Department of Medicine, Faculty of \\ Medicine, Ramathibodi Hospital, Mahidol \\ University, Bangkok, Thailand; ${ }^{2}$ Division \\ of Infectious Diseases, Department of \\ Medicine, Faculty of Medicine, \\ Ramathibodi Hospital, Mahidol \\ University, Bangkok, Thailand; \\ ${ }^{3}$ Ramathibodi Poison Center and Division \\ of Clinical Pharmacology and Toxicology, \\ Department of Medicine, Faculty of \\ Medicine, Ramathibodi Hospital, Mahidol \\ University, Bangkok, Thailand; ${ }^{4}$ Centre \\ for Health Services Research, Faculty of \\ Medicine, The University of Queensland, \\ Brisbane, QLD, Australia
}

Correspondence: Sirasa Ruangritchankul Division of Geriatric Medicine, Department of Medicine, Faculty of Medicine, Ramathibodi Hospital, Mahidol University, 270 Rama VI Road, Ratchathewi, Bangkok, 10400, Thailand Tel +66816404373

Fax +6622012588

Email sirasarama37@gmail.com

\begin{abstract}
The rising of global geriatric population has contributed to increased prevalence of dementia. Dementia is a neurodegenerative disease, which is characterized by progressive deterioration of cognitive functions, such as judgment, language, memory, attention and visuospatial ability. Dementia not only has profoundly devastating physical and psychological health outcomes, but it also poses a considerable healthcare expenditure and burdens. Acetylcholinesterase inhibitors (AChEIs), or so-called anti-dementia medications, have been developed to delay the progression of neurocognitive disorders and to decrease healthcare needs. AChEIs have been widely prescribed in clinical practice for the treatment of Alzheimer's disease, which account for $70 \%$ of dementia. The rising use of AChEIs results in increased adverse drug reactions (ADRs) such as cardiovascular and gastrointestinal adverse effects, resulting from overstimulation of peripheral cholinergic activity and muscarinic receptor activation. Changes in pharmacokinetics (PK), pharmacodynamics (PD) and pharmacogenetics (PGx), and occurrence of drug interactions are said to be major risk factors of ADRs of AChEIs in this population. To date, comprehensive reviews in ADRs of AChEIs have so far been scarcely studied. Therefore, we aimed to recapitulate and update the diverse aspects of AChEIs, including the mechanisms of action, characteristics and risk factors of ADRs, and preventive strategies of their ADRs. The collation of this knowledge is essential to facilitate efforts to reduce ADRs of AChEIs.
\end{abstract}

Keywords: older adults, dementia, acetylcholinesterase inhibitors, adverse drug reactions, drug-drug interactions

\section{Introduction}

Globally, the number of older population aged 60 years or over was 962 million in 2017 and will almost double to reach 2.1 billion by $2050 .^{1,2}$ The rising geriatric population results in an exponential increase in incidence of neurodegenerative disorders such as dementia. ${ }^{3,4}$ Worldwide, the population of people living with dementia was estimated at 50 million in 2017 and is predicted to increase to 131.5 million by $2050 .^{5,6}$ Dementia is described as symptoms related to a cluster of major neurocognitive disorders or conditions which are usually manifested as slowly progressive decline of multiple cortical functions including orientation, comprehension, memory, language, learning skills and problemsolving ability. ${ }^{7}$ The most common type of dementia is AD (50-75\%), followed by vascular dementia (20\%), dementia with Lewy bodies (5\%) and finally frontotemporal lobar dementia $(5 \%) .^{8-10}$ In $\mathrm{AD}$, the progressive loss of 
cholinergic neurons in the basal forebrain leads to a decrease in acetylcholine (ACh) which is essential in cognition and neuroprotection. ${ }^{11}$ Dementia has a devastating impact on healthcare infrastructures in economic and medical aspects. This neurodegenerative disease is one of the leading causes of death and contributors to premature disability and dependency burdens. ${ }^{5,12,13}$ With increased disability, dementia could be overwhelming for caregivers and families, leading to increased healthcare needs. ${ }^{3,12,14-17}$ Appropriate management, including non-pharmacological and pharmacological therapies, are necessary to delay worsening of symptoms and to reduce healthcare burdens. ${ }^{18}$ Antidementia medications are being used worldwide, especially in Alzheimer's disease (AD), which is the most common type of dementia. ${ }^{19}$ One-fourth of older people with dementia are prescribed anti-dementia medications which are classified into two classes: Acetylcholinesterase inhibitors (AChEIs) and N-Methyl-D-aspartate (NMDA) receptor antagonists. $^{20,21}$ AChEIs were the first pharmacological treatment approved by the US Food and Drug Administration (FDA) for $\mathrm{AD}$ and have been reported to be used in $10-20 \%$ of dementia patients. ${ }^{22-25}$

The aging population usually have multiple other chronic diseases as well as behavioral and psychological symptoms of dementia (BPSD), ${ }^{12,22,26-35}$ resulting in the concurrent use of five or more medications or polypharmacy. ${ }^{26}$ The exposure of $82-98 \%$ of people with dementia to polypharmacy was reported in previous studies. $^{36-38}$ This can lead to a greater risk of undesirable or harmful reactions to medications or adverse drug reactions (ADRs). ${ }^{39-41}$ The alterations in pharmacokinetics (PK), pharmacodynamics (PD) and pharmacogenetics (PGx) of AChEIs also result in higher risk of AChEIs' ADR. $^{42-47}$ Over the last decades, there has been an increase in the reports of AChEI-induced ADRs with $70 \%$ being severe and up to $2.3 \%$ being fatal ADRs. ${ }^{48-50}$

Therefore, the significance of the paper is to facilitate effort to address the issue of AChEI-induced ADRs among older patients with dementia. We aim to review and update the diverse aspects of AChEIs such as the mechanisms of action, characteristics and risk factors of ADRs, and preventive strategies of their ADRs.

\section{Search Strategy}

PubMed, Scopus and Web of Science databases were searched for relevant articles published in English from
January 1, 1976 until March 31, 2021. The search terms were "donepezil", "galantamine", "rivastigmine", "acetylcholinesterase inhibitors", “dementia", "Alzheimer's disease", "older adults", "mechanism", "pharmacokinetics", "pharmacodynamics", "pharmacogenetics", "adverse drug reactions", "drug-drug interactions", "prevention". Google Scholar was searched using main keywords for any additional studies.

\section{Acetylcholinesterase Inhibitors Mechanism of Acetylcholinesterase Inhibitors}

ACh is mostly hydrolyzed by acetylcholinesterase (AChE) and butyrylcholinesterase $(\mathrm{BuChE}) .{ }^{51}$ Both enzymes are responsible for rapid hydrolysis of $\mathrm{ACh}$ in synaptic clefts, producing the products: Choline and acetate. AChE predominates in the human brain whereas BuChE is widely distributed in peripheral nervous system (PNS) and other organs such as intestine, heart and liver. ${ }^{52-54}$ In the brain, AChE levels are usually high in synapses while BuChE is distributed in glial cells. ${ }^{53}$ In $\mathrm{AD}$ patients, BuChE has progressively increased activity in particular part of the brain such as hippocampal area and has raised accumulation of $A \beta$-aggregation and neurofibrillary tangles, resulting in the reduction of $\mathrm{ACh} .^{52,55-61}$ Therefore, a class of AChEIs is developed to block both AChE and BuChE in the synaptic clefts to reduce the degradation of Ach. ${ }^{19}$ Furthermore, one AChEI has a pharmacological property for modulation of muscarinic or nicotinic receptors, contributing to enhancement of cholinergic activity. ${ }^{62}$ AChEIs increase cholinergic activities to improve and sustain cognitive functions and ADLs as well as to make better psycho-behavioral symptoms in dementia patients. ${ }^{22}$ However, AChEIs also inhibit rapid hydrolysis of $\mathrm{ACh}$ in PNS including sympathetic autonomic nervous system, and parasympathetic and preganglionic sympathetic neurons. This leads to peripheral adverse outcomes, such as diarrhea, nausea and vomiting, dizziness, and muscle cramping. ${ }^{63}$

The first-generation of AChEIs such as tacrine, velnacrine, and physostigmine were removed from the market because of high incidence rates of potential drug interactions and serious side effects. ${ }^{64}$ Three second-generation AChEIs were rapidly developed to replace the firstgeneration AChEIs. Donepezil, galantamine and rivastigmine have been approved by the FDA for the treatment of AD. Donepezil (58.4\%) is the most frequently 
prescribed AChEIs, followed by rivastigmine (13.6\%) and galantamine $(12.4 \%) .{ }^{22,65-67}$ Donepezil in oral form and rivastigmine transdermal patches have received regulatory approval for the treatment of all stages of AD ranging from mild to severe. ${ }^{19,22,68-80}$ There is no significant difference between the efficacy of these AChEIs in terms of improving psychometric and cognitive scales. ${ }^{81}$ However, three AChEIs differ in both PK and PD properties, ${ }^{82-84}$ as shown in Supplementary Table 1.

\section{Donepezil}

Donepezil was the first AChEI approved by the FDA for AD treatment in 1996. It is a piperidine-based reversible inhibitor of AChE. ${ }^{82,85}$ Donepezil is 500 -fold selective for AChE inhibition in comparison with BuChE. ${ }^{86,87}$ The oral bioavailability is $100 \%$ and time to peak plasma concentration $\left(\mathrm{T}_{\max }\right)$ approximates $3-5$ hours following a single-dose administration. ${ }^{88,89}$ Plasma albumin binding is $75 \%$ and volume of distribution (Vd) is $12 \mathrm{~L} / \mathrm{kg}$. ${ }^{88-90}$ Donepezil readily transports across the blood brain barrier (BBB), resulting in 7-fold higher concentration in the brain compared with plasma. Cytochrome P450 2D6 (CYP2D6) is accounted for the major Phase I metabolism (90\%) and the rest by Cytochrome P450 3A4 (CYP3A4). ${ }^{89,91}$ 6-O-desmethyl donepezil (6DD) is the end product of Phase II metabolism which is excreted via kidney route. ${ }^{88,92}$ The average apparent plasma clearance is approximately $0.13-0.19 \mathrm{~L} / \mathrm{h} / \mathrm{kg}$. According to its elimination half-life (70 hours), it takes around 15 days to reach the steady state. Then, it is conveniently administered as once daily. ${ }^{88,89}$ Both $5 \mathrm{mg}$ and $10 \mathrm{mg}$ once daily administration for 24 weeks could improve cognitive and quality of life scales in mild to moderate $\mathrm{AD}$ patients. ${ }^{93-95}$ The initial dose should be administered initially with $5 \mathrm{mg} /$ day, followed by slow-dose titration every 4-6 weeks along with the clinical status monitoring until reaching the maximum dose of $10 \mathrm{mg}$ for mild to moderate $\mathrm{AD}{ }^{64,95}$ For severe $\mathrm{AD}$, the maximum daily dose of donepezil is $23 \mathrm{mg}$ once daily. ${ }^{76}$

\section{Rivastigmine}

Rivastigmine was approved by the FDA to be marketed in 1997. Rivastigmine is classified as a carbamate substance. ${ }^{81,82,85}$ Its mechanism of action is a slow reversible or pseudo-irreversible inhibition of both $\mathrm{AChE}$ and BuChE. ${ }^{85,96,97}$ The oral bioavailability is poor, approximate $40 \%$ with $\mathrm{T}_{\max }$ ranging from 0.5 to 2 hours following oral single-dose administration. ${ }^{88,98}$ Plasma protein binding is $40 \%$ and $\mathrm{Vd}$ is $1.8-2.7 \mathrm{~L} / \mathrm{kg} .{ }^{88,99,100}$ Rivastigmine easily passes through the BBB to exert activity in the brain. ${ }^{101,102}$ Intestinal esterase is the major enzyme responsible for first pass metabolism and the rest is minimally metabolized by liver cytochrome $\mathrm{P} 450 .{ }^{88}$ The main metabolite is NAP 226-90 which is rapidly excreted by renal system. ${ }^{88}$ The plasma clearance of rivastigmine is estimated to be $1.5 \mathrm{~L} / \mathrm{h} / \mathrm{kg}$. Its half-life is short, nearly 1.5 hours. Therefore, twice-daily dosing is recommended in clinical practice. ${ }^{88,100}$ Several double-blind controlled studies showed significant improvement in cognitive and global functions with 6 month-treatment. ${ }^{103,104}$ Clinical studies pointed out the effective doses of rivastigmine to be 6 to $12 \mathrm{mg}$ per day. ${ }^{64,105}$ Rivastigmine is recommended to start at the dose of $1.5 \mathrm{mg}$ twice-daily as capsules or liquid formulations and slowly titrate up to $6 \mathrm{mg}$ twicedaily at intervals of every 2 to 4 weeks. ${ }^{81,103}$ In terms of other efficacy of rivastigmine, the improvement of peripheral insulin resistance has not been reported. ${ }^{106}$ Transdermal patch is another preparation which delivers rivastigmine constantly into the blood circulation without level fluctuation. ${ }^{71,97,107}$ The therapeutic dose of transdermal patch delivering rivastigmine is $4.6 \mathrm{mg}$ per 24 hours to $13.3 \mathrm{mg}$ per 24 hours in clinical practice. ${ }^{107,108}$ Rivastigmine patch is suggested to be started at $4.6 \mathrm{mg}$ per 24 hours for at least for 4 weeks and then to be increased to $9.5 \mathrm{mg}$ per 24 hours. After a minimum of 6 months a dose of $9.5 \mathrm{mg}$ per 24 hours, $13.3 \mathrm{mg}$ per 24 hours is recommended for well-tolerated patients with progressive cognitive decline. ${ }^{109}$

\section{Galantamine}

Galantamine was approved by the FDA in 2000 for the treatment of AD. ${ }^{110}$ This agent is a tertiary alkaloid-based compound that acts as both rapidly reversible-competitive inhibitor of $\mathrm{AChE}$ and a positive allosteric modulator of nicotinic acetylcholine receptors. ${ }^{62,85,110}$ The oral bioavailability of galantamine ranges from 85 to $100 \%$ with rapid absorption. ${ }^{88,111}$ The $\mathrm{T}_{\max }$ is approximately 52 minutes following a single oral administration. Unlike donepezil, protein binding of galantamine is less than $50 \%$ and the mean $\mathrm{Vd}$ is $2.64 \mathrm{~L} / \mathrm{kg}{ }^{88,111}$ This medication is demethylated and oxidized by CYP2D6 and CYP3A4. The active metabolite of galantamine is sanguinine or O-desmethyl galantamine ${ }^{88,112}$ Galantamine goes through glucuronidation forming a water-soluble metabolite which is excreted via the renal route. ${ }^{88,111,112}$ The total plasma clearance of galantamine is $0.34 \mathrm{~L} / \mathrm{h} / \mathrm{kg}{ }^{113}$ Due to its short half-life of 
6-8 hours, twice-daily dosing is recommended. ${ }^{88,111,113}$ The formulation of galantamine consists of both immediate-release tablets and extended-release capsules. The efficacy of both extended and immediate release tablets of galantamine was studied in a randomized, double-blind, placebo-controlled trails, using doses titrating up to 16 or $24 \mathrm{mg}$ per day for 6 months duration of treatment in patients with mild to moderate AD. ${ }^{104,114,115}$ These studies demonstrated a significant improvement in cognitive and neuropsychiatric scales. ${ }^{114}$ The recommended therapeutic dose of galantamine is $8 \mathrm{mg}$ per day and gradually escalates every 4 weeks up to a maximum daily dose of $24 \mathrm{mg} .{ }^{116}$

Therefore, the safety and effectiveness of AChEIs should be evaluated in older population in whom adverse reactions may be serious. ${ }^{117}$ In terms of efficacy and effectiveness assessment of AChEIs, the common tools for cognitive evaluation includes Mini-Mental-State Examination (MMSE), ${ }^{118}$ Alzheimer's Disease Assessment ScaleCognitive subscale (ADAS-Cog), ${ }^{119}$ and Severe Impairment Battery (SIB). ${ }^{120}$ Other tests are used to measures functional status and psycho-behavioral symptoms are the Basic and Instrumental Activity of Daily Living ${ }^{121-123}$ and Neuropsychiatric inventory (NPI), ${ }^{124}$ respectively. According to previous clinical practice guideline based on systematic reviews, ${ }^{104,125,126}$ AChEIs treatment for dementia contributed to marginally significant improvement of cognitive function, functional and global status, and psychobehavioural symptoms. ${ }^{17,125,127}$ In mild to moderate AD patients, meta-analyses on AChEIs have revealed the results with cognitive improvements on 1.5 points in MMSE and 2.5 points in ADAS-cog, comparing to the placebo. ${ }^{19}$ The Pooled data presented an improvement of 0.1 standard deviations of ADLs ${ }^{104,125}$ and 2 of 144 points in NPI. ${ }^{128}$ Besides cognitive and behavioural improvement, AChEIs have positive effects on balance and gait function without orthostatic hypotension. ${ }^{129}$ However, there is limited evidence of AChEI efficacy and effectiveness in severe dementia, advanced age and long-term treatment. ${ }^{19,130,131}$

\section{Adverse Drug Reactions of Acetylcholinesterase Inhibitors}

The prevalence of AChEI-induced ADRs tends upward significantly in older population with dementia. ${ }^{48}$ In a 16year period study, the number of AChEI-induced ADRs increased from 1924 ADRs in 1998 to 2961 ADRs in 2013. ${ }^{48}$ Most reported cases are serious ADRs (50-70\%) of which $2.3 \%$ are fatal ADRs. ${ }^{48-50}$ AChEIs have a doserelated toxicity and a narrow therapeutic index. Therefore, the prevalence of ADRs has an upward trend with an increasing dose. ${ }^{48}$ Most ADRs of AChEIs are described as type A reactions which are associated with dose and altered PK and PD. However, most type A reactions are potentially preventable In a recent study, preventable ADRs from prescription and administration errors were presented in $2.0 \%$ of all serious cases. ${ }^{48}$ According to the mechanism of AChEI action, overstimulation of central and peripheral muscarinic and nicotinic receptors may contribute to diarrhea, nausea, vomiting, vagotonic effects (bradycardia, heart block, syncope), tremor, insomnia, urinary incontinence, and seizure..$^{63,132-135}$ Common ADRs induced by AChEIs are principally neuropsychiatric (17\%), gastrointestinal (16.2\%), and cardiovascular $(11.2 \%)$ in nature ${ }^{49}$ as a result of overstimulation of peripheral cholinergic activity and muscarinic receptor activation, as revealed in Supplementary Table 2..$^{48,72,83,132,133}$

\section{Gastrointestinal Adverse Effects}

Oral administration of AChEIs increases gastric acid secretion of hydrochloric acid and internal propulsion which lead to the increase of gastrointestinal adverse effects, namely gastrointestinal ulceration and bleeding, especially for the concomitant use of AChEI and NSAIDs. ${ }^{136,137}$ Commonly reported gastrointestinal adverse effects are abdominal pain, nausea, vomiting, diarrhea, and poor appetite. ${ }^{72,133,138-141}$ The increase of gastrointestinal side effects is associated with the rapid escalation of AChEI dose. ${ }^{142}$

\section{Cardiovascular Adverse Effects}

Both conduction and sinus node function gradually deteriorate with advanced age. Moreover, AChEI increases the availability of choline in the heart and vagotonic effects via muscarinic receptors. ${ }^{143,144}$ Cardiovascular side effects are some of the most common peripheral adverse cholinergic effects. Therefore, older adults treated with AChEIs are at greater risk of life-threatening conduction dysfunction such as sinoatrial and atrioventricular block, ${ }^{140,145,146}$ severe sinus bradycardia ${ }^{147}$ and QT interval prolongation with torsades de pointes (TdP). ${ }^{148-150}$ Wandering atrial pacemaker (WAP) is another uncommon cardiac side effect in patients treated with donepezil. This condition is an atrial arrhythmia which presents with at least three distinctly different $\mathrm{P}$ wave morphologies. ${ }^{151}$ Negative chronotropic effects contribute to detrimental 
health outcomes including syncope, pacemaker insertion, falls, fractures, hospitalization. ${ }^{147,152-154}$ However, there is controversy that AChEIs result in negative chronotropic effects. ${ }^{155-158}$ Therefore, older people receiving AChEIs should be routinely asked regarding syncope histories and be evaluated for arrhythmia or bradycardia by physical examination and electrocardiogram. ${ }^{159}$ Concomitant use of AChEIs and drug-induced QT prolongation such as beta-blockers, antiarrhythmic drugs and antipsychotics should be closely monitored by physicians and pharmacists. ${ }^{159}$ In contrast, AChEIs treatment may be correlated with lower risk of cardiovascular events. ${ }^{158}$

\section{Neurological and Psychological Adverse Effects}

Neurological side effects mainly result from excessive activation of nicotinic receptors. Common neurological adverse effects are dizziness, dyskinesia, convulsion, muscle cramps, insomnia, and vivid dream. The epileptic seizure is a very rare neurological adverse effects induced by AChEIs. ${ }^{160,161}$ From previous report, patient with mild AD treated with $10 \mathrm{mg}$ donepezil once daily for 3 weeks presented convulsions during the treatment. ${ }^{160}$ Moreover, AChEI-induced seizures may result from nutritional and metabolic disorders such as hyponatremia. ${ }^{161}$ The vivid dream results from the disorder of brainstem cholinergic systems in processing rapid eye movement sleep. One characteristic of the vivid dream is extremely realistic. Vivid dreams usually appear in patients treated with donepezil in the evening owing to peak plasma concentration at night. ${ }^{63,162}$ Psychiatric adverse outcomes in older adults treated with AChEIs may include worsening of hallucination, anxiety, aggression, and confusion. ${ }^{163,164}$ Psychiatric problems are usually presented in dementia patients treated with high doses of AChEIs.

\section{Respiratory Adverse Effects}

Bronchospasm was presented as a pulmonary side effect after AChEI administration. ${ }^{165}$ Therefore, patients with a history of bronchoconstriction should be closely monitored during treatment. ${ }^{165}$ Furthermore, nasal problems could be presented among patients treated with AChEI. ${ }^{165}$ There is no report of respiratory failure from AChEIs for dementia treatment.

\section{Genitourinary Adverse Effects}

Urinary incontinence may occur after treatment with AChEIs, in particular for galantamine. ${ }^{166}$ The mechanism is related to nicotinic Ach receptor stimulation at the neuromuscular junction, resulting in an increased peripheral ACh.

\section{Dermatological Adverse Effects}

Rivastigmine could be used in the form of a skin patch. The most common skin adverse reaction is irritant contact dermatitis as a local skin reaction which is not associated with an immunological process. Its manifestation is localized erythema and itching. ${ }^{167,168}$ These symptoms usually resolve within 48 hours after patch removal. As a rare dermatological adverse reaction, allergic contact dermatitis is delayed type-IV immunologic reaction and manifests as erythema, vesicles and edema appearing more than 48 hours after rivastigmine patch removal. The lifethreatening skin adverse reaction called Stevens-Johnson Syndrome (SJS) can occur in patients treated with oral or dermal administration and was reported in patients treated with galantamine. ${ }^{138,167-169}$

\section{Uncommon Adverse Effects}

According to post-marketing surveillance, a rare dystonic reaction called Pisa syndrome has been reported in patients receiving AChEIs. This syndrome is described as tonic flexion of the head and trunk one side accompanied by slight axial rotation. ${ }^{170}$ The pathophysiology of the syndrome results from dopaminergic-cholinergic imbalance. Pisa syndrome was reported in a patients receiving $9 \mathrm{mg}$ per day rivastigmine for 2 years. ${ }^{171,172}$ However, this abnormal syndrome disappeared when the drug dose was decreased. ${ }^{171}$ Rhabdomyolysis and neuroleptic malignant syndromes are uncommon side effects which have been reported in older adults receiving donepezil. ${ }^{173-175}$ Furthermore, hemolytic anemia, syndrome of inappropriate antidiuretic hormone (SIADH), ${ }^{161}$ and severe hepatitis ${ }^{176}$ also present as uncommon adverse effects in clinical practice.

AChEI-induced adverse effects may provide chance for prescribing cascades. AChEIs activate muscarinic receptors in urinary tract, leading to strong contraction of detrusor muscle and urinary incontinence. Therefore, bladder anticholinergic agents such as oxybutynin, tolterodine, trospium and solifenacin are usually used to relieve urge incontinence which called AChEI-induced urinary incontinence prescribing cascade. ${ }^{177}$ Another common 
prescribing cascade is AChEI-induced rhinorrhea which is concomitant use of rhinorrhea medications to relieve side effects of AChEIs. The rhinorrhea medications consist of antihistamine, nasal anticholinergics and nasal glucocorticoids. ${ }^{178}$ These co-medications may contribute to negative side effects. Therefore, physicians should consider dose reduction of AChEIs instead of adding other medications to treat adverse effects of AChEIs. ${ }^{179}$

\section{Factors Associated with Adverse Drug Reactions of Acetylcholinesterase Inhibitors in Older Adults with Dementia}

In geriatric patients with dementia, changes in PK and PD are major risk factors of ADRs. In terms of PK, hepatic and renal functions usually decline in these patients, resulting in decreased drug elimination. Older patients are vulnerable to get an uneventful ADRs from these medications according to their sensitivity to the pharmacodynamic effects. ${ }^{180}$ Additionally, patients with AD are prone to be sensitive to ADRs as a result of increased BBB permeability and decreased P-gp activity in the brain. ${ }^{43,101,102,181,182}$ Polypharmacy is common in aging populations and is an important risk factor for drugrelated problems (DRPs) such as potentially inappropriate medications (PIMs), drug-drug interactions (DDIs), ADRs and poor compliance. ${ }^{183,184}$ ADRs derived from DDIs, PIMs or poor compliance are often reported in older patients with dementia. ${ }^{183,184}$ ADRs are major causes of hospitalization, morbidity and mortality in older people with dementia. ${ }^{185,186}$

\section{Changes in Pharmacokinetics}

PK is what an individual's body does to a medication after its administration, and refers to absorption, distribution, metabolism and excretion. ${ }^{42-47}$ In geriatric population, the alteration of absorption does not lead to major adverse effects whereas changes in distribution, metabolism and excretion play important roles in clinical outcomes. The alterations of PK and PD of AChEIs among older people living with dementia were presented in Tables 1 and 2.

\section{Absorption}

Age-related gastrointestinal tract changes often affect the oral absorption. Hypochlorhydria in older adults alleviate the degree of absorption of weakly basic drugs. Furthermore, reduced splanchnic blood flow and gastrointestinal motility as well as delayed gastric emptying time result in longer staying of drug in the gastrointestinal tract and delaying absorption of the drug. Older adults treated with donepezil presented a significant increase in mean $\mathrm{T}_{\max }$ but not in plasma level concentration contributing to slower donepezil's absorption. ${ }^{86,90} \mathrm{In}$ contrast, the bioavailability and absorption of rivastigmine have no significant change with advancing age. ${ }^{187}$ Concomitant administration of galantamine with food delays $T_{\max }$ by 1.5 hours and slows its absorption rate but does not affect the extent of absorption. ${ }^{74}$ A moderate food effect was found in previous studies of rivastigmine.${ }^{54}$ Food slows the absorption of rivastigmine and reduces $\mathrm{T}_{\max }$ by $30 \%{ }^{54,188}$ Therefore, the coadministration of food and galantamine or rivastigmine is indicated to reduce cholinergic adverse effects such as nausea and vomiting. Conversely, food intake has no significant effect on the absorption of donepezil. ${ }^{54,189}$

Rivastigmine could also be administered via a skin patch. Age-related changes in skin includes atrophy of epidermis and dermis and decreased blood perfusion, leading to reduced drug absorption via the skin. ${ }^{190}$ Nevertheless, age-related changes to drug absorption have minimal effects on the pharmacotherapy of dermal medications.

\section{Distribution}

Many factors affect volume of distribution. Patients with dementia are more likely to experience malnutrition and frailty as a result of inability to feed by themselves, changes in feeding behaviours, and difficulty with swallowing. ${ }^{191}$ Changes in the body composition of older adults with dementia also occur including, $10-15 \%$ reduction in total body water, $25-30 \%$ reduction in muscle mass, and a $25-30 \%$ relative increase in body fat. ${ }^{192,193}$ The aging and frailty processes in this group of patients also contributes to a $10-20 \%$ reduction in serum albumin concentration which plays a major role in plasma protein binding. ${ }^{193-196}$ Medication that predominately binds albumin such as donepezil ( $75 \%$ bind to albumin), a reduction in albumin binding may contribute to the rising of unbound fraction being pharmacologically active, resulting in greater potency and toxicity. ${ }^{88,90}$ Furthermore, donepezil may displace other high-protein binding medications such as warfarin, benzodiazepine and valproate, leading to an increased unbound form of these medications and serious adverse effects. Due to age-related changes, the Vd throughout the whole body of donepezil is substantially 
Table I The Changes in Pharmacokinetics of Acetylcholinesterase Inhibitors Among Older Adults Living with Dementia

\begin{tabular}{|c|c|c|c|c|}
\hline \multirow[t]{2}{*}{ Physiologic Changes } & \multicolumn{3}{|c|}{ Causes of PK Changes } & \multirow[t]{2}{*}{ PK Consequences } \\
\hline & $\begin{array}{l}\text { Aging } \\
\text { Process }\end{array}$ & Frailty & Dementia & \\
\hline Reduction in GI mobility ${ }^{86,90}$ & $\checkmark \checkmark$ & $\checkmark \checkmark$ & & Increased in mean $\mathrm{T}_{\max }$ of donepezil \\
\hline $\begin{array}{l}\text { Reduction in splanchnic blood } \\
\text { flow }^{86,90}\end{array}$ & $\checkmark \checkmark$ & & & Increased in mean $\mathrm{T}_{\max }$ of donepezil \\
\hline $\begin{array}{l}\text { Reduction in tissue blood } \\
\text { perfusion } 190\end{array}$ & $\checkmark \checkmark$ & & & Reduction in rivastigmine's absorption via skin \\
\hline $\begin{array}{l}\text { Atrophy of epidermis and } \\
\text { dermis } 190\end{array}$ & $\checkmark \checkmark$ & & & Reduction in rivastigmine's absorption via skin \\
\hline $\begin{array}{l}\text { Reduction in serum } \\
\text { albumin } 88,90,193-196\end{array}$ & $\checkmark \checkmark$ & $\checkmark \checkmark$ & $\checkmark \checkmark$ & $\begin{array}{l}\text { Increased free fraction in plasma of high-protein binding AChEI } \\
\text { (donepezil) }\end{array}$ \\
\hline $\begin{array}{l}\text { Reduction in hepatic mass and } \\
\text { size }^{88,89,91,111,112,201-205}\end{array}$ & $\checkmark \checkmark$ & & & $\begin{array}{l}\text { Reduced first-pass metabolism (phase I) and hepatic clearance } \\
\text { of donepezil, galantamine and rivastigmine }\end{array}$ \\
\hline $\begin{array}{l}\text { Increased of inflammatory } \\
\text { process }{ }^{198-200}\end{array}$ & & $\begin{array}{c}\checkmark \checkmark \\
\text { Reduced phase } \\
\text { II metabolism }\end{array}$ & & $\begin{array}{l}\text { Downregulation in metabolism and transporter pathway of } \\
\text { donepezil, galantamine and rivastigmine }\end{array}$ \\
\hline
\end{tabular}

Abbreviations: PK, pharmacokinetics; PD, pharmacodynamics; AChEl, acetylcholinesterase inhibitor; GI, gastrointestinal; $T_{\max }$ Time to maximum serum concentration.

increased by approximately $40 \%$, resulting in a prolonged half-life. ${ }^{90,197}$

\section{Metabolism}

Liver CYP enzymes system plays a major role in drug metabolism and may be affected by increasing age. CYP2C19 functions are reduced with age while other isoenzymes show minimal reduction or no change. ${ }^{45}$ In contrast, there is no significant change in phase II metabolism, especially conjugation in older adults. However, phase II metabolism and downregulation of the transporter pathway of AChEIs are decreased in frail older adults, leading to a greater risk of drug toxicity. ${ }^{198-200}$ The decrease of drug metabolism in the geriatric population, especially in phase I metabolism, results from a $30 \%$ and $40 \%$ reduction in liver mass and in hepatic blood flow, respectively. ${ }^{201-205}$ The reduction in drug metabolism may account for decreased hepatic clearance, prolonged half-life and increased dose-dependent ADRs. In terms of AChEIs, there are diverse pharmacological properties and differences of clinical outcomes. Data from clinical trials of geriatric patients with $\mathrm{AD}$ reveal that the steady-state concentrations of galantamine are $40 \%$ higher than those in a healthy younger population as a result of reduced galantamine's metabolism. ${ }^{88,111,112,138}$ Based on a population pharmacokinetic analysis, the hepatic clearance of donepezil and of rivastigmine has a tendency to decrease with increasing age. ${ }^{88,89,91,187}$ Apart from age-related changes in metabolism, most older adults with dementia have multiple chronic diseases including hepatic diseases or cirrhosis, which may lead to decreased hepatic function and drug metabolism. The clearance of both galantamine and rivastigmine was reduced by $25 \%$ and $65 \%$, respectively in patients with moderate hepatic impairment (Child-Pugh score of 7-9). ${ }^{88,111,121}$ Hence, dose adjustment is recommended for these populations. The use of galantamine for such patients should be initiated with a low dose (4 mg per day) and slowly titrated to a maximum daily dose (16 $\mathrm{mg}$ per day). ${ }^{88,111,138}$ However, no data is available on the use of galantamine or rivastigmine in patients with severe hepatic impairment (Child-Pugh score of 10-15). ${ }^{8,111,112,138}$ Consequently, the use of galantamine or rivastigmine in patients with severe hepatic impairment is contraindicated in clinical practice. ${ }^{138}$ A recent study showed a $20 \%$ reduction in the clearance of donepezil in dementia patients with cirrhosis. ${ }^{206}$ However, there is no clinically significant alteration in the PK of donepezil in AD 
patients with moderate or severe hepatic impairment. ${ }^{206,207}$ This may explain why dose modification of donepezil is not required.

\section{Excretion}

After metabolism, most substances are transformed to products that are readily excreted via the kidneys. As a results of age-related physiological changes, the reduction in renal blood flow (50\%), renal mass and size (20-30\%), and number of nephrons $(60 \%)$, lead to a decline in drug excretion and drug half-life prolongation. ${ }^{208}$ Apart from metabolism changes, dosage adjustment should be done based on renal function which is calculated from laboratory measurement (serum creatinine) by using a mathematical equation including the Cockcroft-Gault (CG) formula to ensure proper drug dose for older adults. ${ }^{45,46,209}$ However, serum creatinine level in older frail individuals may not accurately present renal function because of decreased muscle mass. ${ }^{209}$ Older AD patients presented a 30\% reduction in renal clearance of galantamine, compared with healthy individuals. ${ }^{210}$ As a consequence of increasing age and frailty, the clearance rate of galantamine, rivastigmine and donepezil in older patients with $\mathrm{AD}$ is reduced, compared to healthy individuals. ${ }^{138,210}$ The clearance of galantamine and rivastigmine is decreased by $25 \%$ and $64 \%$, respectively in $\mathrm{AD}$ patients with moderate renal impairment. ${ }^{138}$ This PK alteration may necessitate dose modification and close monitoring to avoid adverse outcomes. ${ }^{138} \mathrm{~A}$ total daily dose of galantamine should not exceed $16 \mathrm{mg}$ in patients with moderate renal decline or creatinine clearance $9-59 \mathrm{~mL} / \mathrm{min}^{138}$ whereas specific-dose adjustment of rivastigmine is not indicated. ${ }^{211}$ Nevertheless, the use of galantamine is not recommended given the insufficient data for patients with severe renal impairment or creatinine clearance less than $9 \mathrm{~mL} / \mathrm{min}^{138}$ On the contrary, donepezil disposition is not affected by renal dysfunction. The renal clearance of donepezil in patients with moderate to severe renal impairment has no difference to sex- and age-matched healthy population despite donepezil and its metabolites are mostly excreted by kidneys. In a population pharmacokinetic study of $\mathrm{AD}$ patients with moderate to severe renal impairment, there is no clinically significant change of PK or PD parameters of donepezil, compared with healthy population. Therefore, dose adjustments are not necessary in $\mathrm{AD}$ patients with renal impairment. ${ }^{64,207}$

As a result of decreased elimination of rivastigmine, dose adjustments with close monitoring should be done. Nevertheless, no study has been reported for rivastigmine transdermal patches in $\mathrm{AD}$ patients with renal or hepatic impairment. Therefore, rivastigmine transdermal patches should be avoided in AD patients with severe renal or hepatic impairment. ${ }^{107,108}$

\section{Changes in the Blood-Brain Barrier}

The BBB is a highly selective semipermeable layer of endothelial cells which limits the access of water-soluble and large molecules transporting from blood circulation into the brain parenchyma. Older adults with dementia have changes in the permeability and integrity of the BBB, as presented in Table 2. BBB mechanism includes reabsorption of CSF and efflux pumps for molecules such as p-glycoprotein (P-gp) which assists the maintenance of hemostasis in the brain and in the clearance of betaamyloid. $^{43,101,102}$ P-gp is a phosphorylated protein encoded by multidrug resistance gene 1 (MDR1) and belongs to the family of ATP-binding cassette (ABC) membrane transporters. ${ }^{102,212}$ It is located on the apical surface of endothelial cells and is involved in limiting the transfer of small molecules into the brain. ${ }^{213,214}$ With aging process and dementia, levels and activity of P-gp have a tendency to decline. ${ }^{101,102,181,215}$ Furthermore, micro-disruption of the $\mathrm{BBB}$ is found in patients with dementia, contributing to increased allowance of some medications across BBB around the disruption areas. ${ }^{181}$ These changes may lead to increased permission of AChEIs to the brain as a predisposing factor of AChEIinduced ADRs in this population. ${ }^{43}$

\section{Changes in Pharmacodynamics}

By definition, PD is described as what medication does to the body such as receptor binding and chemical interaction. ${ }^{42-47}$ The changes of PD are difficult to predict and evaluate in individuals. In the aging process, the sensitive affinity of receptors for particular medications may change. Moreover, the number of receptor sites may alter and may impact on the efficacy of many medications. The geriatric population is more susceptible to certain central nervous system (CNS) adverse outcomes of AChEIs due to increased permeability of the BBB and decreased P-gp activity. ${ }^{101,102,181,182,215}$ Furthermore, high sensitivity to cholinergic receptors in the brain and the reduction in homeostasis are found in the older adult population. ${ }^{45,46,216}$ These alterations result in an elevated responses to AChEIs and contribute to PNS and CNS cholinergic ADRs, as presented in Table 2. However, 
Table 2 The Changes in Pharmacokinetics and Pharmacodynamics of Acetylcholinesterase Inhibitors Among Older Adults Living with Dementia

\begin{tabular}{|c|c|c|c|c|}
\hline \multirow[t]{2}{*}{ Physiologic Changes } & \multicolumn{3}{|c|}{ Causes of PK or PD Changes } & \multirow[t]{2}{*}{ PK Consequences } \\
\hline & $\begin{array}{c}\text { Aging } \\
\text { Process }\end{array}$ & Frailty & Dementia & \\
\hline $\begin{array}{l}\text { Reduction in hepatic blood } \\
\text { flow }^{88,89,91,111,|1| 2,201-205}\end{array}$ & $\checkmark \checkmark$ & & & Increased half-life of donepezil, galantamine and rivastigmine \\
\hline $\begin{array}{l}\text { Reduction in renal blood } \\
\text { flow }^{138,208,210,211}\end{array}$ & $\checkmark \checkmark$ & & & $\begin{array}{l}\text { Reduced renal clearance of donepezil, galantamine and } \\
\text { rivastigmine }\end{array}$ \\
\hline $\begin{array}{l}\text { Reduction in number of } \\
\text { nephron }{ }^{138,208,210,211}\end{array}$ & $\checkmark \checkmark$ & & & Increased half-life of donepezil, galantamine and rivastigmine \\
\hline $\begin{array}{l}\text { Reduction in glomerular infiltration } \\
\text { rate }^{138,208,210,211}\end{array}$ & $\checkmark \checkmark$ & $\checkmark \checkmark$ & & Increased half-life of donepezil, galantamine and rivastigmine \\
\hline Physiologic changes & & & & PD consequences \\
\hline  & $\checkmark \checkmark$ & & $\checkmark \checkmark$ & $\begin{array}{l}\text { Increased permeability of donepezil, galantamine and } \\
\text { rivastigmine across BBB }\end{array}$ \\
\hline 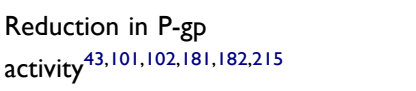 & $\checkmark \checkmark$ & & $\checkmark \checkmark$ & $\begin{array}{l}\text { Increased permeability of donepezil, galantamine and } \\
\text { rivastigmine across BBB }\end{array}$ \\
\hline $\begin{array}{l}\text { High sensitivity to cholinergic } \\
\text { receptor } 45,46,216\end{array}$ & $\checkmark \checkmark$ & & & $\begin{array}{c}\text { Increased response to donepezil, galantamine and } \\
\text { rivastigmine }\end{array}$ \\
\hline
\end{tabular}

Abbreviations: PK, pharmacokinetics; PD, pharmacodynamics; BBB, blood-brain barrier; P-gp, P-glycoprotein.

changes in the PD of AChEIs in older patients with dementia have not been extensively explored.

\section{Changes in Pharmacogenetics}

Pharmacogenetics is defined as genetic variations in individuals which contribute to different responses to medications. PGx plays a major role in ADRs and therapeutic failures (TFs). Polymorphism of CYP enzymes for AChEIs results in PK and PD difference. ${ }^{84,217}$ In terms of AChEIs, PGx of encoded gene on P-gp, CYP2D6, and CYP3A4 plays an important role in PK of donepezil and galantamine. ${ }^{218}$ Interesting studies presented genetic variations of single nucleotide polymorphisms (SNP) in cholinergic markers on $\mathrm{AChE}$ and $\mathrm{BuChE}$ which have effects on clinical responses to AChEIs as well. ${ }^{82,219}$ Moreover, polymorphism in the gene encoding choline acetyltransferase (ChAT), acetylcholine biosynthetic enzyme, and a genetic variation of paraoxonase-1 (PON-1) 192Q/R (rs662) which influences the activity of this arylesterase, are involved as the prognostic indicators of response to AChEIs. ${ }^{220,221}$ Pharmacogenetic considerations for AChEIs should be heeded because they could help predict drug toxicity and efficacy in individuals. In recent decades, genetic polymorphism on CYP2D6 genotype was increasingly studied in various populations. ${ }^{22-225}$ CYP2D6 phenotypes are categorized into four types of metabolizers: Poor metabolizers (PMs), intermediate metabolizers (IMs), extensive metabolizers (EMs), and ultra-rapid metabolizers (UMs). PMs have functional deficiency of CYP2D6 due to mutated allele of CYP2D6. EMs have normal functions of CYP2D6 while UMs have a very low concentration of AChEI owing to multiple copies of CYP2D6 gene. IMs metabolize medications with a rate between PMs and EMs. ${ }^{222,223,225}$ According to PGx of CYP2D6 (PGXCYP2D6), approximately $30 \%$ of older AD patients have poor metabolite of galantamine and donepezil. ${ }^{226}$ This situation can be explained by the phenotypic profile of CYP2D6 genotypes being associated with the presence of the APOE-4 allele. $^{227-229}$ Furthermore, the prevalence of each CYP2D6 polymorphism differs according to race and ethnicity. ${ }^{84,230}$ In Caucasian populations, PMs, IMs, EMs and UMs account for approximately $5-10 \%, 10-17 \%, 70-80 \%$ and $3-5 \%$ of individuals, respectively. ${ }^{231,232}$ Asians, Africans and African Americans have a greater percentage of reduced-function of CYP2D6 (50\%), compared with Caucasians (26\%). ${ }^{233}$ CYP3A4 polymorphism is not responsible for the variation in metabolism of donepezil and galantamine. The effect of genetic variation in ATP-binding cassette sub-family 
B member 1 (ABCB1) on membrane transporter P-gp plays an important role in donepezil transporters across the BBB and in the clearance of amyloid $\beta$ (A $\beta$ ) peptide related to APOE, $\mathrm{ABCB} 1$ gene polymorphisms which have an impact on distribution, excretion, and absorption of donepezil. ${ }^{102,212,234,235}$

\section{Drug-Drug Interactions}

DDI is defined as the pharmacological activities of one drug changed by the concomitant administration of another medication. $^{236}$ Generally, drug interactions are responsible for $20 \%$ to $30 \%$ of ADRs. Over $30 \%$ of reported ADRs caused by AChEIs result from DDIs. ${ }^{237}$ The major risk factors for DDIs are polypharmacy and age-related PK and PD changes. ${ }^{238,239}$ DDIs are classified into two types: PK and PD drug interactions. By definition, PK drug interaction involves one medication altering the absorption, distribution, transport, metabolism or excretion of another medication. ${ }^{240}$ PD drug interaction is defined as one medication changing the response to another medication. ${ }^{240}$ CYP enzymes-mediated and transporter-mediated PK drug interactions as well as synergistic or antagonistic PD drug interactions are common DDIs among dementia patients treated with AChEIs. ${ }^{241-243}$ Inducers and inhibitors of CYP2D6 and CYP3A4 enzyme play important roles in the mechanism of PK drug interactions of donepezil and galantamine. ${ }^{226,244} \mathrm{P}$-gp inducers and inhibitors are involved in transporter-mediated PK drug interactions of donepezil, which is considered a weak P-gp substrate. ${ }^{245}$
Potent CYP2D6 and CYP3A4 inhibitors such as antidepressants (paroxetine, fluoxetine), and antifungal drugs (ketoconazole) contribute to increased plasma concentration of donepezil and galantamine, as shown in Table 3. ${ }^{138,242,246-249}$ The adverse outcomes may be hypercholinergic effects of AChEIs, such as bradycardia, diarrhea and hypersalivation. However, there is no significant CYP2D6 and CYP3A4 inducers of donepezil and galantamine. In terms of transporter-mediated PK drug interactions, PK of donepezil is affected by P-gp inhibitors and inducers. Most medications, which are transported by P-gp, are also metabolized by CYP3A4..$^{214,245,250}$ Many $\mathrm{P}$-gp inhibitors and inducers are also inhibitors and inducers of CYP3A4. Therefore, many DDIs are associated with inhibition or induction of both CYP3A4 and P-gp. ${ }^{250}$ The most common P-gp inhibitors in patients with dementia are antibiotics (azithromycin, clarithromycin, erythromycin), cardiovascular medications (carvedilol, verapamil) and antiplatelets (cilostazol, ticagrelor), resulting in the rising of donepezil plasma concentration. ${ }^{250-252}$ There was the clinical report of cardiotoxicity owing to coadministration of donepezil and cilostazol. ${ }^{252}$ Due to P-gp interaction with cilostazol, the concentration of donepezil in the heart tissue was increased, leading QT prolongation. ${ }^{252}$ In the case of P-gp inducers, the plasma concentration of donepezil is decreased by carbamazepine, phenobarbital, phenytoin and rifampicin, ${ }^{250-252}$ as presented in Table 4.

Pharmacoepidemiological studies in people with dementia have revealed that anticholinergics, antidepressants, antipsychotics, non-steroidal anti-inflammatory

Table 3 Common CYP Enzymes-Mediated Pharmacokinetic Drug Interactions of Acetylcholinesterase Inhibitors in Older Adults Living with Dementia

\begin{tabular}{|c|c|c|c|}
\hline PK Drug Interactions & CYP2D6 & CYP3A4 & Outcomes \\
\hline $\begin{array}{l}\text { Strong Inhibitors }{ }^{138,242,246-} \\
249\end{array}$ & $\begin{array}{l}\text { Antidepressants } \\
\text { Bupropion } \\
\text { Duloxetine } \\
\text { Fluoxetine } \\
\text { Paroxetine } \\
\text { Sertraline } \\
\text { Antiarrhythmic } \\
\text { drugs } \\
\text { Amiodarone } \\
\text { Antipsychotics } \\
\text { Aripiprazole } \\
\text { Haloperidol }\end{array}$ & $\begin{array}{c}\text { Antibiotics } \\
\text { Erythromycin } \\
\text { Antifungal drugs } \\
\text { Fluconazole } \\
\text { Ketoconazole } \\
\text { Antiarrhythmic } \\
\text { drugs } \\
\text { Amiodarone } \\
\text { Antipsychotics } \\
\text { Haloperidol } \\
\text { Antidepressants } \\
\text { Sertraline }\end{array}$ & $\begin{array}{l}\text { Increased plasma concentration of donepezil and } \\
\text { galantamine } \\
\text { Hypercholinergic outcomes } \\
\text { Hypersalivation, abdominal pain, diarrhea, nausea, vomiting }\end{array}$ \\
\hline
\end{tabular}

Abbreviations: PK, pharmacokinetics; CYP, cytochrome P450; CYP2D6, cytochrome P450 2D6; CYP3A4, cytochrome P450 3A4. 
Table 4 Common Transporter-Mediated Pharmacokinetic Drug Interactions of Acetylcholinesterase Inhibitors in Older Adults Living with Dementia

\begin{tabular}{|c|c|c|}
\hline $\begin{array}{l}\text { Transporter-Mediated PK Drug } \\
\text { Interactions }\end{array}$ & Medications & Outcomes \\
\hline P-gP inhibitors ${ }^{250-252}$ & $\begin{array}{l}\text { Antibiotics } \\
\text { Erythromycin } \\
\text { Azithromycin } \\
\text { Clarithromycin } \\
\text { Antifungal drugs } \\
\text { Itraconazole } \\
\text { Ketoconazole } \\
\text { Cardiovascular } \\
\text { drugs } \\
\text { Verapamil } \\
\text { Carvedilol } \\
\text { Antiplatelet } \\
\text { Cilostazol } \\
\text { Ticagrelor }\end{array}$ & $\begin{array}{l}\text { Increased plasma concentration of Donepezil as P-gP substrate } \\
\text { Hypercholinergic outcomes hypersalivation, QT prolongation, } \\
\text { diarrhea, nausea, vomiting }\end{array}$ \\
\hline P-gp inducers ${ }^{250-252}$ & $\begin{array}{c}\text { Anticonvulsants } \\
\text { Carbamazepine } \\
\text { Phenytoin } \\
\text { Phenobarbital } \\
\text { Antituberculosis } \\
\text { drugs } \\
\text { Rifampicin }\end{array}$ & Decreased plasma concentration of Donepezil as P-gp substrate \\
\hline
\end{tabular}

Abbreviations: PK, pharmacokinetics; P-gp, P-glycoprotein.

drugs (NSAIDs), and cardiovascular drugs are common co-medications with AChEIs, resulting in PD drug interactions. $^{237,243,253,254}$ Synergistic PD drug interactions of AChEIs with cholinomimetics or cholinergic agonists have additional cholinergic effects such as hypersalivation, diarrhea, nausea, and vomiting, as presented in Table $5 .^{255-257}$ Many antagonistic PD drug interactions of AChEIs are related to changes in PD from advancing age and to dementia processes. In the aging process, a reduction in the number of cholinergic and dopaminergic neurons and dopamine $\mathrm{D}_{2}$ receptors are reported. Therefore, the uses of anticholinergics and antipsychotics which affect cholinergic and dopaminergic neurotransmitters, potentially interfere with the activity of cholinesterase inhibitors and can cause adverse clinical outcomes. ${ }^{253,254,258,259}$ The clinical report described rigidity, parkinsonism and immobilization in AD patients treated with donepezil and risperidone which these adverse symptoms resolved after risperidone was discontinued. ${ }^{260}$ Furthermore, concomitant use of beta-blockers, calcium channel blockers or antiarrhythmics in older patients with dementia treated with AChEIs may result in adverse cardiovascular effects such as bradyarrhythmia, heart block, syncope and QT prolongation, ${ }^{63,243,261}$ as presented in Table 5 .

\section{Principles for Prescribing Acetylcholinesterase Inhibitors Recommendations for Prescribing Acetylcholinesterase Inhibitors}

AChEI should be initiated at a low efficient dose and titrated slowly upward. The starting dose of donepezil is $5 \mathrm{mg}$ once daily. Donepezil dosage should not be adjusted too quickly because the time to reach the steady state is within 15 days. Therefore, donepezil should be slowly titrated after the first dose is started over 4-6 weeks. Older adults with moderate to severe AD could slowly titrate the donepezil dose to $23 \mathrm{mg}$ per day, ${ }^{262}$ as presented in Supplementary Table 1. However, gastrointestinal complaints and poor appetite may be reported in patients receiving high donepezil doses. ${ }^{75,139,262,263}$ Among patients with mild to moderate hepatic insufficiency, a low dose (5 mg daily) consumption 
Table 5 Pharmacodynamic Interactions in Older Adults with Dementia

\begin{tabular}{|c|c|c|c|}
\hline PD Drug Interactions & Interactions & Mechanism Effects & Adverse Outcomes \\
\hline Anticholinergics + AChEls ${ }^{138,243,253,254}$ & Antagonistic & $\begin{array}{l}\text { Decreased } \\
\text { acetylcholine in CNS }\end{array}$ & $\begin{array}{l}\text { Constipation, delirium, cognitive impairment, } \\
\text { urinary retention } \\
\text { Antagonized the effects } \\
\text { of } A C h E l s\end{array}$ \\
\hline $\begin{array}{l}\text { Cholinomimetics or cholinergic agonists + } \\
\mathrm{AChEls}^{255-257}\end{array}$ & Synergistic & $\begin{array}{l}\text { Increased acetylcholine } \\
\text { in PNS }\end{array}$ & $\begin{array}{l}\text { Hypersalivation, abdominal pain, diarrhea, nausea, } \\
\text { vomiting, }\end{array}$ \\
\hline Beta blockers + AChEls ${ }^{63,243,261}$ & Synergistic & $\begin{array}{c}\text { Decreased sympathetic } \\
\text { Increased vagotonic } \\
\text { effects }\end{array}$ & $\begin{array}{c}\text { Bradyarrhythmia, heart block, prolonged } \mathrm{QT} \text {, torsades } \\
\text { de pointes syncope }\end{array}$ \\
\hline $\begin{array}{l}\text { Calcium channel blockers + } \\
\text { AChEls }^{63,243,261}\end{array}$ & Synergistic & $\begin{array}{c}\text { Decreased sympathetic } \\
\text { Increased vagotonic } \\
\text { effects }\end{array}$ & $\begin{array}{c}\text { Bradyarrhythmia, heart block, prolonged QT, torsades } \\
\text { de pointes, syncope }\end{array}$ \\
\hline Antiarrhythmic drugs $+\mathrm{AChEls}^{63,243,261}$ & Synergistic & $\begin{array}{c}\text { Decreased sympathetic } \\
\text { Increased vagotonic } \\
\text { effects }\end{array}$ & $\begin{array}{l}\text { Bradyarrhythmia, heart block, torsades de pointes, } \\
\text { syncope }\end{array}$ \\
\hline Antipsychotics + AChEls $242,243,258,259$ & Antagonistic & $\begin{array}{l}\text { Decreased dopamine } \\
\text { in striatum }\end{array}$ & $\begin{array}{c}\text { Rigidity, parkinsonism, worsening of extrapyramidal } \\
\text { effects }\end{array}$ \\
\hline NSAIDs + AChEls ${ }^{136,137,237,243}$ & Synergistic & $\begin{array}{l}\text { Increased gastric acid } \\
\text { secretion }\end{array}$ & Gastrointestinal ulcer \\
\hline
\end{tabular}

Abbreviations: PD, pharmacodynamics; AChEls, acetylcholinesterase inhibitors; NSAIDs, non-steroidal anti-inflammatory drugs; CNS, central nervous system; PNS, peripheral nervous system.

of donepezil is safe and the use of its doubling dose should be monitored. ${ }^{264}$ Galantamine is a daily oral medication ranging from 8 to $24 \mathrm{mg}$ per day, ${ }^{116}$ as shown in Supplementary Table 1. Galantamine doses must be adjusted for people with moderate hepatic impairment. Furthermore, galantamine should not be recommended to patients with severe liver and kidney dysfunction. Rivastigmine may be a good choice for older demented patients exposed to polypharmacy to reduce the incidence of $\mathrm{PK}$ drug interactions related to CYP enzymes. Rivastigmine prescriptions start at $1.5 \mathrm{mg}$ and could be gradually increased to $6 \mathrm{mg}$ twice a day, ${ }^{64,81,103,105}$ as shown in Supplementary Table 1. Rivastigmine transdermal patches are usually recommended for dementia patients with severe gastrointestinal side effects from oral administration. Transdermal patches have a long half-life and are easily applied only once a day. The dose of rivastigmine in a patch can be titrated from $4.6 \mathrm{mg}$ per 24 hours to $13.3 \mathrm{mg}$ per 24 hours. ${ }^{107-109}$ However, some patients treated with a transdermal patch may develop dermatological side effects such as pruritus or an allergic reaction. Therefore, patients should be examined for adverse skin reactions during treatment. $^{108}$

\section{Contraindication and Caution in the Prescribing of Acetylcholinesterase Inhibitors}

Allergic reaction to the medication itself and chemicals in the same structural group is an absolute contraindication. Donepezil is a piperidine-based compound. ${ }^{81,82,85}$ Rivastigmine is derived from carbamate compound whereas galantamine is belonged to alkaloid substance. ${ }^{62,81,82,85}$ Rivastigmine patches are contraindicated for patients with suggestive allergic contact dermatitis. ${ }^{107-109}$ Galantamine is also contraindicated for patients with severe hepatic and renal dysfunction. ${ }^{212}$ Additionally, patients with sick sinus syndrome (SSS) and second or third heart block should avoid using AChEIs. ${ }^{138,140,141}$ AChEIs should be used with cautions in people with severe hepatic impairment, severe obstructive pulmonary disease, active gastrointestinal ulcers or bleeding, seizure and significant conduction abnormalities such as supraventricular conduction problems, and arrhythmias. ${ }^{138,140,141}$ However, older patients treated with AChEIs rarely develop cholinergic crisis in the clinical practice. 
Table 6 Prevention Strategies for Adverse Drug Reactions of Acetylcholinesterase Inhibitors

\begin{tabular}{|c|c|}
\hline Medication Problems & Management \\
\hline DDls ${ }^{47,238,272-275,277,280,28 I}$ & $\begin{array}{l}\text { Evaluate drug interactions via application (Micromedex) } \\
\text { Evaluate drug-disease interactions by Beers Criteria }\end{array}$ \\
\hline Poor compliance $47,272-275,282-288$ & $\begin{array}{l}\qquad \begin{array}{l}\text { Easily understandable drug labels } \\
\text { Use simplest regimens }\end{array} \\
\text { Encourage memory techniques (alarm clock, calendar) } \\
\text { Evaluate health literacy (language, education, dementia) }\end{array}$ \\
\hline Polypharmacy $47,272-275$ & $\begin{array}{l}\text { Comprehensive medication review } \\
\text { Minimize number of physicians and hospital visits } \\
\text { Prescribe only necessary medications }\end{array}$ \\
\hline The discontinuation of $\mathrm{AChEls}{ }^{268}$ & $\begin{array}{l}\text { Weighting the risks and the benefits of continuous } A C h E l s \text { use } \\
\text { Consider deprescribing AChEls in patients with lack of treatment response, severe cognitive function, } \\
\text { significantly impaired functional status }\end{array}$ \\
\hline $\mathrm{PIMs}^{47,272-275,278,279}$ & $\begin{array}{l}\text { Comprehensive medication review } \\
\text { Evaluate potentially inappropriate medication for older adults with dementia following Beers Criteria }\end{array}$ \\
\hline Miscommunication ${ }^{272-275,286-288}$ & $\begin{array}{l}\text { Evaluate health literacy (language, education, dementia) } \\
\text { Ensure the plan with patients and caregivers or family members } \\
\text { Encourage technology and technique for older patients to make proper pharmacological plan and management }\end{array}$ \\
\hline $\begin{array}{l}\text { Age-related physiological } \\
\text { changes } 47,270,272-275\end{array}$ & $\begin{array}{c}\text { Check physiological problems related to drug administration such as cognitive impairment, visual and auditory } \\
\text { problems, and bone-joint deformity }\end{array}$ \\
\hline $\begin{array}{l}\text { Age-related changes in } \\
\mathrm{PK}^{47,270,272-275}\end{array}$ & $\begin{array}{l}\text { Evaluate weight and nutritional status, refers to protein levels } \\
\text { Evaluate patients' hepatic and renal function }\end{array}$ \\
\hline $\begin{array}{l}\text { Age-related changes in } \\
P^{47,270,272-275}\end{array}$ & $\begin{array}{c}\text { Start low and slowly titrate AChEls due to be highly sensitive } \\
\text { drug-induced action on cholinergic receptors }\end{array}$ \\
\hline
\end{tabular}

Abbreviations: DDIs, drug-drug interactions; PIMs, potentially inappropriate medications; PK, pharmacokinetics; PD, pharmacodynamics; AChEls, acetylcholinesterase inhibitors.

\section{Recommendations for Discontinuation of Acetylcholinesterase Inhibitors}

The continuous use of AChEIs should be often weighted the risks and the benefits. According to the Food and Drug Administration Adverse Event Reporting System database, serious ADRs related to AChEIs were reported, especially in long-term treatment. ${ }^{135,136,179,213,265,266}$ Advanced dementia patients may be offered unnecessary treatment that may not provide positive effects, resulting in increased adverse outcomes. ${ }^{267}$ Therefore, many studies offered recommendations to discontinue AChEI treatment in particular conditions to optimize medication prescribing. ${ }^{268}$ The common reason for deprescribing AChEIs were lack of response, significantly impaired functional status, severe cognitive impairment (MMSE score $<10$ ), and side effects. ${ }^{268}$ Besides minimized medication prescribing, the benefits of AChEI discontinuation are improved medication non-adherence, and reduced DDI, medication management burden and cost of medications. ${ }^{269}$
The discontinuation of AChEIs should be slowly tapered the dose by halving the previous dose and stepping down to the lowest available dose. ${ }^{269}$ The abrupt cessation should be done in patients with experiencing ADRs. After discontinuation, physicians should closely monitor the withdrawal symptoms and the changes of cognitive function, psycho-behavioral symptoms and functional status. ${ }^{269}$

\section{Strategies to Prevent Adverse Drug Reactions of Acetylcholinesterase Inhibitors}

Many strategies have been developed and implemented to prevent ADRs in patients using AChEIs, as shown in Table 6. Minimizing effective dose is required to reduce the occurrence of adverse outcomes. The "start low go slow" strategy is widely recommended as the lowest initial dose, slow-dose titration and close monitoring. ${ }^{270,271}$ The dose adjustment of AChEIs is recommended according to 
the alteration of PK or PD. ${ }^{47,270,272-275}$ Furthermore, older patients usually have comorbidities for which multiple medications are taken, resulting in DRPs including potential DDIs, drug-disease interactions, inappropriate medications and medication non-adherence..$^{270,272-274,276}$ Thus, comprehensive medication reviews and optimizing medications prescribing are necessary to address DRPs. ${ }^{275}$ Another potential strategy could be using tools such as the Micromedex Drug Interaction Database ${ }^{277}$ and the 2019 American Geriatrics Society Beers criteria ${ }^{278}$ to evaluate DDIs and PIMs, respectively. ${ }^{238,279}$ The discontinuation of AChEIs in older adults with particular circumstances including lack of treatment response, severe cognitive function, significantly impaired functional status, could have reduced DDIs and PIMs. ${ }^{268}$ Moreover, computerized alert systems for screening prescriptions and flagging DDIs and PIMs could also prevent ADRs. ${ }^{275,280,281}$ Medication non-adherence is another major DRP in older adults, resulting from language barriers, complex regimens and physiological changes including cognitive impairment, visual and auditory problems and bone-joint deformities. ${ }^{282-286}$ Many techniques could provide benefits to people with medication non-adherence; for example, readily openable containers, clearly written instructions in large print, the simple possible dosage regimens and supporting technology (alarm clock and drug calendar). ${ }^{287,288}$

\section{Conclusions}

AChEIs have been widely prescribed to delay worsening of cognitive functions and psycho-behavioral problems in older people living with dementia. In the aging population, age-related PK and PD changes, and multiple comorbidities lead to altered pharmacological responses and increased ADRs. Furthermore, geriatric people are more likely to be sensitive to pharmacological toxicity. The most common negative effects of AChEIs are adverse neuropsychiatric, gastrointestinal, and cardiovascular outcomes. Thus, prescribing of AChEIs for dementia treatment should carefully consider both risks and benefits. The discontinuation of AChEIs in older people with particular circumstances such as lack of treatment response, severe cognitive impairment and side effects, could reduce DRPs. Many strategies have been developed to prevent adverse effects. The "start low go slow" strategy as well as comprehensive medication review are highly recommended to address ADRs.

\section{Abbreviation}

ABCB1, ATP-binding cassette sub-family B member 1; A $\beta$, amyloid $\beta$; Ach, acetylcholine; AChE, acetylcholinesterase; AChEIs, acetylcholinesterase inhibitors; AD, Alzheimer's disease; ADRs, adverse drug reactions; AGS Beers Criteria, American Geriatrics Society Beers Criteria; BBB, blood brain barrier; BPSD, behavioral and psychological symptoms; BuChE, butyrylcholinesterase; CG, Cockcroft-Gault; ChAT, choline acetyltransferase; CNS, central nervous system; CSF, cerebrospinal fluid; CYP, cytochrome P450; CYP2D6, cytochrome P450 2D6; CYP3A4, cytochrome P450 3A4; DDIs, drug-drug interactions; DRPs, Drugrelated problems; Ems, extensive metabolisers; FDA, Food and Drug Administration; GI, gastrointestinal; IMs, intermediate metabolisers; MDR1, multidrug resistance gene 1; nAChRs, nicotinic acetylcholine receptors; NMDA, N-Methyl-D-aspartate; NSAIDs, non-steroidal antiinflammatory drugs; PD, pharmacodynamics; P-gp, p-glycoprotein; PIMs, potentially inappropriate medications; PGx, pharmacogenetics; PGx-CYP2D6, pharmacogenetics of CYP2D6; PK, pharmacokinetics; PMs, poor metabolisers; PNS, peripheral nervous system; PON-1, paraoxonase-1; SIADH, syndrome of inappropriate antidiuretic hormone; SJS, Stevens-Johnson Syndrome; SNP, single nucleotide polymorphism; SSS, sick sinus syndrome; TdP, torsades de pointes; TFs, therapeutic failures; $\mathrm{T}_{\max }$, time to peak plasma concentration; Ums, ultra-rapid metabolisers; Vd, volume of distribution; WAP, wandering atrial pacemaker; 6DD, 6-O-desmethyl donepezil.

\section{Acknowledgments}

The authors would like to thank Leila Shafiee Hanjani, Centre for Health Services Research, Faculty of Medicine, The University of Queensland, for providing valuable advice and comments.

\section{Author Contributions}

All authors made substantial contributions to conception and design, acquisition of data, or analysis and interpretation of data; took part in drafting the article or revising it critically for important intellectual content; agreed to submit to the current journal; gave final approval of the version to be published; and agree to be accountable for all aspects of the work.

\section{Funding}

The authors received no financial support for the research. 


\section{Disclosure}

The authors declare no potential conflicts of interest regarding this work.

\section{References}

1. World Health Organization. World report on ageing and health. Geneva: World Health Organization; 2015. Available from http:// www.who.int/ageing/events/world-report-2015-launch. Accessed November 22, 2020

2. Wilson T. An introduction to population projections for Australia. Australian Population Studies.2019;3(1):40-56.

3. Prince MJ, Wimo A, Guerchet MM, Ali GC, Wu Y-T, Prina M. World Alzheimer Report 2015; The Global Impact of Dementia: An analysis of prevalence, incidence, cost and trends. London: Alzheimer's Disease International, 2015. Available from: http:// www.alz.co.uk/research/world-report-2015. Accessed November 22, 2020.

4. Ahmadi-Abhari S, Guzman-Castillo M, Bandosz P, et al. Temporal trend in dementia incidence since 2002 and projections for prevalence in England and Wales to 2040: modelling study. BMJ. 2017;358:j2856. doi:10.1136/bmj.j2856

5. World Health Organization. Dementia. Geneva: World Health Organization; 2019. Available from: http://www.who.int/newsroom/fact-sheets/detail/dementia. Accessed November 21, 2020.

6. Alzheimer's Disease International. Dementia Statistics. London: Alzheimer's Disease International; 2017. Available from: https:// www.alz.co.uk/research/statistics. Accessed November 21, 2020.

7. ICD-10. Organic, including symptomatic, mental disorders (F00-F09); 2016. Available from: https://icd.who.int/browse10/ 2016/en\#/F00-F09. Accessed November 24, 2020..

8. Dementia Australia 2018a. Types of Dementia. Australia: Dementia Australia; 2018. Available from: https://www.demen tia.org.au/information/about-dementia/types-of-dementia.

Accessed December 2, 2020.

9. Dementia Australia 2018c. Alzheimer's disease. Australia: Dementia Australia; 2018. Available from: https://www.demen tia.org.au/about-dementia/types-of-dementia/alzheimer-disease. Accessed December 2, 2020.

10. Alzheimer's Association. 2016 Alzheimer's Disease Facts and Figures. Alzheimers Dement. 2016;12(4):459-509.

11. Epperly T, Dunay MA, Boice JL. Alzheimer Disease: pharmacologic and Nonpharmacologic Therapies for Cognitive and Functional Symptoms. Am Fam Physician. 2017;95(12):771-778.

12. Australian Institute of Health and Welfare 2012. Dementia in Australia. Cat. no. AGE 70. Canberra: AIHW; 2012. Available from: https://www.aihw.gov.au/getmedia/13995.pdf.aspx. Accessed November 25, 2020.

13. Australian Bureau of Statistics 2019. Causes of Death, Australia, 2019, Catalogue No. 3303.0, ABS. Canberra: Australian Bureau of Statistics (ABS); 2019. Available from: http://www.abs.gov.au/ ausstats/abs@.nsf/mf/3303.0. Accessed December 2, 2020.

14. Winblad B, Amouyel P, Andrieu S, et al. Defeating Alzheimer's disease and other dementias: a priority for European science and society. Lancet Neurol. 2016;15(5):455-532.

15. Malone DC, McLaughlin TP, Wahl PM, et al. Burden of Alzheimer's disease and association with negative health outcomes. Am J Manag Care. 2009;15(8):481-488.

16. Sharma S, Mueller C, Stewart R, et al. Predictors of falls and fractures leading to hospitalization in people with dementia: a representative cohort study. J Am Med Dir Assoc. 2018;19 (7):607-612. doi:10.1016/j.jamda.2018.03.009
17. The National Centre for Social and Economic Modelling NATSEM (2016) Economic Cost of Dementia in Australia 2016-2056; 2017 Feb. Available from: http://www.dementia.org. au/files/NATIONAL/documents/The-economic-cost-of-dementiain-Australia-2016-to-2056.pdf. Accessed November 12, 2020.

18. Dyer SM, Harrison SL, Laver K, et al. An overview of systematic reviews of pharmacological and non-pharmacological interventions for the treatment of behavioral and psychological symptoms of dementia. Int Psychogeriatr. 2017;30(03):1-15.

19. Birks J. Cholinesterase inhibitors for Alzheimer's disease. Cochrane Database Syst Rev. 2006;1:CD005593.

20. O'Brien JT, Holmes C, Jones M, et al. Clinical practice with anti-dementia drugs: a revised (third) consensus statement from the British Association for Psychopharmacology. J Psychopharmacol. 2017;31(2):147-168. doi:10.1177/0269881116680924

21. Rabins PV, Rummans T, Schneider LS, et al. Practice Guideline for the Treatment of Patients with Alzheimer's Disease and Other Dementias. 2nd ed. USA: American Psychiatric Association; 2014. doi:10.1176/appi.books. 9780890423967.152139

22. Australian Institute of Health and Welfare 2019. Dispensing patterns for anti-dementia medications 2016-17. Cat. no. AGE 95. Canberra: AIHW; 2019. Available from: https://www.aihw.gov. au/reports/dementia/dispensing-patterns-for-anti-dementiamedications/contents. Accessed November 20, 2020.

23. Calvó-Perxas L, Turró-Garriga O, Vilalta-Franch J, et al. Trends in the Prescription and Long-Term Utilization of Antidementia Drugs Among Patients with Alzheimer's Disease in Spain: a Cohort Study Using the Registry of Dementias of Girona. Drugs Aging. 2017;34 (4):303-310. doi:10.1007/s40266-017-0446-x

24. Moraes FS, Souza MLC, Lucchetti G, Lucchetti ALG. Trends and disparities in the use of cholinesterase inhibitors to treat Alzheimer's disease dispensed by the Brazilian public health system - 2008 to 2014: a nation-wide analysis. Arq Neuropsiquiatr. 2018;76 (7):444-451. doi:10.1590/0004-282x20180064

25. Pariente A, Helmer C, Merliere Y, Moore N, Fourrier-Réglat A, Dartigues JF. Prevalence of cholinesterase inhibitors in subjects with dementia in Europe. Pharmacoepidemiol Drug Saf. 2008;17 (7):655-660. doi:10.1002/pds.1613

26. Clague F, Mercer SW, McLean G, Reynish E, Guthrie B. Comorbidity and polypharmacy in people with dementia: insights from a large, population-based cross-sectional analysis of primary care data. Age Ageing. 2017;46(1):33-39.

27. Parsons C. Polypharmacy and inappropriate medication use in patients with dementia: an underresearched problem. Ther $A d v$ Drug Saf. 2017;8(1):31-46. doi:10.1177/2042098616670798

28. Hoffmann F, van den Bussche H, Wiese B, et al. Impact of geriatric comorbidity and polypharmacy on cholinesterase inhibitors prescribing in dementia. BMC Psychiatry. 2011;11:190. doi:10.1186/1471-244X-11-190

29. Kales HC, Gitlin LN, Lyketsos CG. Assessment and management of behavioral and psychological symptoms of dementia. BMJ. 2015;350(mar02 7):h369. doi:10.1136/bmj.h369

30. Masopust J, Protopopová D, Vališ M, et al. Treatment of behavioral and psychological symptoms of dementias with psychopharmaceuticals: a review. Neuropsychiatr Dis Treat. 2018;14:1211-1220. doi:10.2147/NDT.S163842

31. Gabryelewicz T. Pharmacological treatment of behavioral symptoms in dementia patients. Przegl Lek. 2014;71(4):215-220.

32. Andersen F, Viitanen M, Halvorsen DS, Straume B, Engstad TA. Co-morbidity and drug treatment in Alzheimer's disease. A cross sectional study of participants in the dementia study in northern Norway. BMC Geriatr. 2011;11:58. doi:10.1186/1471-2318-11-58 
33. Fereshtehnejad SM, Johnell K, Eriksdotter M. Anti-dementia drugs and co-medication among patients with Alzheimer's disease: investigating real-world drug use in clinical practice using the Swedish Dementia Quality Registry (SveDem). Drugs Aging. 2014;31(3):215-224. doi:10.1007/s40266-014-0154-8

34. Crugel M, Paton G, Singh P, et al. Antipsychotics in people with dementia: frequency of use and rationale for prescribing in a UK mental health service. Psychiatrist. 2012;36(5):165-169. doi:10.1192/pb.bp.111.034579

35. Seitz DP, Adunuri N, Gill SS, Gruneir A, Herrmann N, Rochon P. Antidepressants for agitation and psychosis in dementia. Cochrane Database Syst Rev. 2011;2:CD008191.

36. Kable A, Fullerton A, Fraser S, et al. Comparison of potentially inappropriate medications for people with dementia at admission and discharge during an unplanned admission to hospital: results from the SMS dementia study. Healthcare (Basel). 2019;7(1):8. doi:10.3390/healthcare7010008

37. Molist-Brunet N, Sevilla-Sa'nchez D, Ambla's-Novellas J, et al. Optimizing drug therapy in patients with advanced dementia: a patient-centered approach. Eur Geriatr Med. 2014;5(1):66-71. doi:10.1016/j.eurger.2013.10.011

38. von Renteln-kruse W, Neumann L, Klugmann B, et al. Geriatric patients with cognitive impairment: patient characteristics and treatment results on a specialized ward. Dtsch Arztebl Int. 2015;112(7):103-112.

39. Maher RL Jr, Hanlon JT, Hajjar ER. Clinical consequences of polypharmacy in elderly. Expert Opin Drug Saf. 2014;13 (1):57-65. doi:10.1517/14740338.2013.827660

40. Rodrigues MC, Oliveira C. Drug-drug interactions and adverse drug reactions in polypharmacy among older adults: an integrative review. Rev Lat Am Enfermagem. 2016;24:e2800. doi:10.1590/1518-8345.1316.2800

41. Wastesson JW, Morin L, Tan ECK, Johnell K. An update on the clinical consequences of polypharmacy in older adults: a narrative review. Expert Opin Drug Saf. 2018;17(12):1185-1196. doi:10.1080/14740338.2018.1546841

42. Reeve E, Trenaman SC, Rockwood K, Hilmer SN. Pharmacokinetic and pharmacodynamic alterations in older people with dementia. Expert Opin Drug Metab Toxicol. 2017;13 (6):651-668. doi:10.1080/17425255.2017.1325873

43. Mehta DC, Short JL, Hilmer SN, Nicolazzo JA. Drug access to the central nervous system in Alzheimer's disease: preclinical and clinical insights. Pharm Res. 2015;32(3):819-839.

44. Massoud L, Agha HA, Taleb M. Pharmacokinetic and pharmacodynamic changes in elderly people. World j Pharm Med. 2017;3 (11):14-23.

45. Hutchison LC, O'Brien CE. Changes in pharmacokinetics and pharmacodynamics in the elderly patient. $J$ Pharm Prac. 2007;20:4-12. doi:10.1177/0897190007304657

46. Mangoni AA, Jackson SH. Age-related changes in pharmacokinetics and pharmacodynamics: basic principles and practical applications. $\mathrm{Br} J$ Clin Pharmacol. 2004;57(1):6-14. doi:10.1046/j.1365-2125.2003.02007.x

47. Wooten JM. Pharmacotherapy considerations in elderly adults. South Med J. 2012;105(8):437-445. doi:10.1097/ SMJ.0b013e31825fed90

48. Kröger E, Mouls M, Wilchesky M, et al. Adverse Drug Reactions Reported with Cholinesterase Inhibitors: an Analysis of 16 Years of Individual Case Safety Reports from VigiBase. Ann Pharmacother. 2015;49(11):1197-1206. doi:10.1177/ 1060028015602274

49. Pariente A, Sanctussy DJ, Miremont-Salamé G, et al. Factors associated with serious adverse reactions to cholinesterase inhibitors: a study of spontaneous reporting. CNS Drugs. 2010;24 (1):55-63. doi:10.2165/11530300-000000000-00000
50. Ali TB, Schleret TR, Reilly BM, Chen WY, Abagyan R. Adverse Effects of Cholinesterase Inhibitors in Dementia, According to the Pharmacovigilance Databases of the United-States and Canada. PLoS One. 2015;10(12):e0144337.

51. Silva T, Reis J, Teixeira J, Borges F. Alzheimer's disease, enzyme targets and drug discovery struggles: from natural products to drug prototypes. Ageing Res Rev. 2014;15:116-145.

52. Guillozet AL, Smiley JF, Mash DC, Mesulam MM. Butyrylcholinesterase in the life cycle of amyloid plaques. Ann Neurol. 1997;42(6):909-918. doi:10.1002/ana.410420613

53. Giacobini E. Selective inhibitors of butyrylcholinesterase: a valid alternative for therapy of Alzheimer's disease? Drugs Aging. 2001;18(12):891-898. doi:10.2165/00002512-200118120-00001

54. Weinstock M. Selectivity of cholinesterase inhibition: clinical implications for the treatment of Alzheimer's disease. CNS Drugs. 1999;12(4):307-323. doi:10.2165/00023210-19991204000005

55. Mesulam MM, Geula C. Butyrylcholinesterase reactivity differentiates the amyloid plaques of aging from those of dementia. Ann Neurol. 1994;36(5):722-727. doi:10.1002/ana.410360506

56. Op Den Velde W, Stam FC. Some cerebral proteins and enzyme systems in Alzheimer's presenile and senile dementia. J Am Geriatr Soc. 1976;24(1):12-16. doi:10.1111/j.1532-5415.1976. tb03247.x

57. Perry EK, Perry RH, Blessed G, Tomlinson BE. Changes in brain cholinesterases in senile dementia of Alzheimer type. Neuropathol Appl Neurobiol. 1978;4(4):273-277. doi:10.1111/ j.1365-2990.1978.tb00545.x

58. Geula C, Darvesh S. Butyrylcholinesterase, cholinergic neurotransmission and the pathology of Alzheimer's disease. Drugs Today (Barc). 2004;40(8):711-721. doi:10.1358/ dot.2004.40.8.850473

59. Arendt T, Bruckner MK, Lange M, Bigl V. Changes in acetylcholinesterase and butyrylcholinesterase in Alzheimer's disease resemble embryonic development - a study of molecular forms. Neurochem Int. 1992;21(3):381-396. doi:10.1016/0197-0186(92) 90189-X

60. Davies P. Neurotransmitter-related enzymes in senile dementia of the Alzheimer type. Brain Res. 1979;171(2):319-327. doi:10.1016/0006-8993(79)90336-6

61. Wright CI, Geula C, Mesulam MM. Neurological cholinesterases in the normal brain and in Alzheimer's disease: relationship to plaques, tangles, and patterns of selective vulnerability. Ann Neurol. 1993;34(3):373-384. doi:10.1002/ana.410340312

62. Maelicke A. Allosteric modulation of nicotinic receptors as a treatment strategy for Alzheimer's disease. Dement Geriatr Cogn Disord. 2000;11(Suppl 1):11-18. doi:10.1159/ 000051227

63. Gauthier S. Cholinergic adverse effects of cholinesterase inhibitors in Alzheimer's disease: epidemiology and management. Drugs Aging. 2001;18(11):853-862. doi:10.2165/00002512200118110-00006

64. Thompson S, Lanctôt KL, Herrmann N. The benefits and risks associated with cholinesterase inhibitor therapy in Alzheimer's disease. Expert Opin Drug Saf. 2004;3(5):425-440.

65. Patel M, Joshi A, Suthar J, Desai S. Drug utilization pattern in patients with different types of dementia in Western India. Int J Alzheimers Dis. 2014;2014:435202.

66. Li Q, He S, Chen Y, et al. Donepezil-based multi-functional cholinesterase inhibitors for treatment of Alzheimer's disease. Eur J Med Chem. 2018;158:463-477. doi:10.1016/j. ejmech.2018.09.031

67. Cheewakriengkrai L, Gauthier S. A 10-year perspective on donepezil. Expert Opin Pharmacother. 2013;14(3):331-338. doi: $10.1517 / 14656566.2013 .760543$ 
68. FDA approved drug products. Available from: http://www.access data.fda.gov/scripts/cder/drugsatfda/index.cfm. Accessed 19 November 2020.

69. Howard R, McShane R, Lindesay J, et al. Donepezil and memantine for moderate-to-severe Alzheimer's disease. $N$ Engl J Med. 2012;366(10):893-903. doi:10.1056/NEJMoa1106668

70. Rodda J, Carter J. Cholinesterase inhibitors and memantine for symptomatic treatment of dementia. BMJ. 2012;344:e2986. doi:10.1136/bmj.e2986

71. Birks JS, Grimley EJ. Rivastigmine for Alzheimer's disease. Cochrane Database Syst Rev. 2015;4:CD001191.

72. Tan CC, Yu JT, Wang HF, et al. Efficacy and safety of donepezil, galantamine, rivastigmine, and memantine for the treatment of Alzheimer's disease: a systematic review and meta-analysis. J Alzheimers Dis. 2014;41(2):615-631. doi:10.3233/JAD-132690

73. Di Santo SG, Prinelli F, Adorni F, et al. A meta-analysis of the efficacy of donepezil, rivastigmine, galantamine, and memantine in relation to severity of Alzheimer's disease. J Alzheimers Dis. 2013;35(2):349-361. doi:10.3233/JAD-122140

74. Tsoi KK, Chan JY, Chan FC, et al. Monotherapy is good enough for patients with mild-to moderate Alzheimer's disease: a network meta-analysis of 76 randomized controlled trials. Clin Pharmacol Ther. 2019;105(1):121-130. doi:10.1002/cpt.1104

75. Deardorff WJ, Feen E, Grossberg GT. The Use of Cholinesterase Inhibitors Across All Stages of Alzheimer's Disease. Drugs Aging. 2015;32(7):537-547. doi:10.1007/s40266-015-0273-x

76. Farlow MR, Salloway S, Tariot PN, et al. Effectiveness and tolerability of high-dose $(23 \mathrm{mg} / \mathrm{d})$ versus standard-dose $(10 \mathrm{mg} /$ d) donepezil in moderate to severe Alzheimer's disease: a 24 week, randomized, double-blind study. Clin Ther. 2010;32 (7):1234-1251. doi:10.1016/j.clinthera.2010.06.019

77. Sabbagh M, Cummings J, Christensen D, et al. Evaluating the cognitive effects of donepezil $23 \mathrm{mg} / \mathrm{d}$ in moderate and severe Alzheimer's disease: analysis of effects of baseline features on treatment response. BMC Geriatr. 2013;13:56. doi:10.1186/14712318-13-56

78. Molinuevo JL, Frölich L, Grossberg GT, et al. Responder analysis of a randomized comparison of the $13.3 \mathrm{mg} / 24 \mathrm{~h}$ and $9.5 \mathrm{mg} / 24$ $\mathrm{h}$ rivastigmine patch. Alzheimers Res Ther. 2015;7(1):9. doi:10.1186/s13195-014-0088-8

79. Farlow MR, Grossberg GT, Sadowsky $\mathrm{CH}$, Meng $\mathrm{X}$, Somogyi MA. 24-week, randomized, controlled trial of rivastigmine patch $13.3 \mathrm{mg} / 24 \mathrm{~h}$ versus $4.6 \mathrm{mg} / 24 \mathrm{~h}$ in severe Alzheimer's dementia. CNS Neurosci Ther. 2013;19 (10):745-752. doi:10.1111/cns.12158

80. Farlow MR, Grossberg G, Gauthier S, Meng X, Olin JT. The ACTION study: methodology of a trial to evaluate safety and efficacy of a higher dose rivastigmine transdermal patch in severe Alzheimer's disease. Curr Med Res Opin. 2010;26 (10):2441-2447. doi:10.1185/03007995.2010.513849

81. Colović MB, Krstić DZ, Lazarević-Pašti TD, Bondžić AM, Vasić VM. Acetylcholinesterase inhibitors: pharmacology and toxicology. Curr Neuropharmacol. 2013;11(3):315-335.

82. Noetzli M, Eap CB. Pharmacodynamic, pharmacokinetic and pharmacogenetic aspects of drugs used in the treatment of Alzheimer's disease. Clin Pharmacokinet. 2013;52(4):225-241. doi:10.1007/s40262-013-0038-9

83. Campos C, Rocha NB, Vieira RT, et al. Treatment of Cognitive Deficits in Alzheimer's disease: a psychopharmacological review. Psychiatr Danub. 2016;28(1):2-12.

84. Cacabelos R. Pharmacogenomics and therapeutic prospects in Alzheimer's disease. Expert Opin Pharmacother. 2005;6 (12):1967-1987. doi:10.1517/14656566.6.12.1967

85. Lane RM, Potkin SG, Enz A. Targeting acetylcholinesterase and butyrylcholinesterase in dementia. Int J Neuropsychopharmacol. 2006;9(1):101-124. doi:10.1017/S1461145705005833
86. Heydorn WE. Donepezil (E2020): a new acetylcholinesterase inhibitor. Review of its pharmacology, pharmacokinetics, and utility in the treatment of Alzheimer's disease. Expert Opin Investig Drugs. 1997;6(10):1527-1535. doi:10.1517/13543784.6.10.1527

87. Kosasa T, Kuriya Y, Matsui K, Yamanishi Y. Inhibitory effects of donepezil hydrochloride (E2020) on cholinesterase activity in brain and peripheral tissues of young and aged rats. Eur J Pharmacol. 1999;386(1):7-13. doi:10.1016/S0014-2999(99)00741-4

88. Gauthier S. Acetylcholinesterase inhibitors in the treatment of Alzheimer's disease. Exp Opin Invest Drugs. 1999;8:1511-1520. doi:10.1517/13543784.8.10.1511

89. Tiseo PJ, Rogers SL, Friedhoff LT. Pharmacokinetic and pharmacodynamic profile of donepezil $\mathrm{HCl}$ following evening administration. Br J Clin Pharmacol. 1998;46(Suppl 1):13-18. doi:10.1046/j.1365-2125.1998.0460s 1013.x

90. Ohnishi A, Mihara M, Kamakura H, et al. Comparison of the pharmacokinetics of E2020, a new compound for Alzheimer's disease, in healthy young and elderly subjects. J Clin Pharmacol. 1993;33(11):1086-1091. doi:10.1002/j.1552-4604.1993.tb01945.x

91. Coin A, Pamio MV, Alexopoulos C, et al. Donepezil plasma concentrations, CYP2D6 and CYP3A4 phenotypes, and cognitive outcome in Alzheimer's disease. Eur J Clin Pharmacol. 2016;72 (6):711-717. doi:10.1007/s00228-016-2033-1

92. Riyath AA, Ammar BB, Faris TA. In vitro kinetic study of donepezil N-oxide metabolites. Irq J Pharm. 2011;11:1-9.

93. Winblad B, Engedal K, Soininen H, et al. Donepezil Nordic Study Group. A 1-year, randomized, placebo-controlled study of donepezil in patients with mild to moderate AD. Neurology. 2001;57 (3):489-495. doi:10.1212/WNL.57.3.489

94. Mohs RC, Doody RS, Morris JC, et al.; “312" Study Group. A 1-year, placebo-controlled preservation of function survival study of donepezil in AD patients. Neurology. 2001;57(3):481-488. doi:10.1212/WNL.57.3.481

95. Rogers SL, Farlow MR, Doody RS, et al.; Donepezil Study Group. A 24-week, double-blind, placebo-controlled trial of donepezil in patients with Alzheimer's disease. Neurology. 50;1998:136-145. doi:10.1212/WNL.50.1.136

96. Potocnik F. Dementia. S Afr J Psychiatr. 2013;19(3):141-152.

97. Jann MW. Rivastigmine, a new generation cholinesterase inhibitor for the treatment of Alzheimer's disease. Pharmacotherapy. 2000;20(1):1-12. doi:10.1592/phco.20.1.1.34664

98. Hossain M, Jhee SS, Shiovitz T, et al. Estimation of the absolute bioavailability of rivastigmine in patients with mild to moderate dementia of the Alzheimer's type. Clin Pharmacokinet. 2002;41 (3):225-234. doi:10.2165/00003088-200241030-00006

99. Obburu JV, Tammara V, Lesko L, et al. Pharmacokinetic, pharmacodynamic modeling of rivastigmine, a cholinesterase inhibitor, in patients with Alzheimer's disease. J Clin Pharmacol. 2001;41(10):1082-1090. doi:10.1177/00912700122012689

100. Spencer CM, Noble S. Rivastigmine: a review of its use in Alzheimer's disease. Drugs Aging. 1998;13(5):391-411. doi:10.2165/00002512-199813050-00005

101. Banks WA. Drug delivery to the brain in Alzheimer's disease: consideration of the blood-brain barrier. Adv Drug Deliv Rev. 2012;64(7):629-639. doi:10.1016/j.addr.2011.12.005

102. van Assema DM, Lubberink M, Bauer M, et al. Blood-brain barrier P-glycoprotein function in Alzheimer's disease. Brain. 2012;135(Pt 1):181-189. doi:10.1093/brain/awr298

103. Rösler M, Anand R, Cicin-Sain A, et al. Efficacy and safety of rivastigmine in patients with Alzheimer's disease: international randomised controlled trial. BMJ. 1999;318(7184):633-638. doi:10.1136/bmj.318.7184.633

104. Raina P, Santaguida P, Ismaila A, et al. Effectiveness of cholinesterase inhibitors and memantine for treating dementia: evidence review for a clinical practice guideline. Ann Intern Med. 2008;148 (5):379-397. doi:10.7326/0003-4819-148-5-200803040-00009 
105. Farlow MR. Update on rivastigmine. Neurologist. 2003;9 (5):230-234. doi:10.1097/01.nrl.0000087724.73783.5f

106. Isik AT, Bozoglu E, Eker D. aChE and BuChE inhibition by rivastigmin have no effect on peripheral insulin resistance in elderly patients with Alzheimer disease. J Nutr Health Aging. 2012;16(2):139-141. doi:10.1007/s12603-011-0095-4

107. Greenspoon J, Herrmann N, Adam DN. Transdermal rivastigmine: management of cutaneous adverse events and review of the literature. CNS Drugs. 2011;25(7):575-583. doi:10.2165/ 11592230-000000000-00000

108. Amanatkar HR, Grossberg GT. Transdermal rivastigmine in the treatment of Alzheimer's disease: current and future directions. Expert Rev Neurother. 2014;14(10):1119-1125. doi:10.1586/ 14737175.2014.955852

109. Lefevre G, Sedek G, Jhee SS, et al. Pharmacokinetics and pharmacodynamics of the novel Daily rivastigmine transdermal patch compared with twice-daily capsules in Alzheimer's disease patients. Clin Pharmacol Ther. 2008;83(1):106-114. doi:10.1038/sj.clpt.6100242

110. Sramek JJ, Frackiewicz EJ, Cutler NR. Review of the acetylcholinesterase inhibitor galantamine. Expert Opin Investig Drugs. 2000;9(10):2393-2402. doi:10.1517/13543784.9.10.2393

111. Bickel U, Thomsen T, Weber W, et al. Pharmacokinetics of galanthamine in humans and corresponding cholinesterase inhibition. Clin Pharmacol Ther. 1991;50(4):420-428. doi:10.1038/clpt.1991.159

112. Bachus R, Bickel U, Thomsen T, Roots I, Kewitz H. The O-demethylation of the antidementia drug galanthamine is catalysed by cytochrome P450 2D6. Pharmacogenetics. 1999;9:661-668. doi:10.1097/00008571-199912000-00001

113. Kewitz H. Pharmacokinetics and metabolism of galanthamine. Drugs Today. 1997;33:265-272. doi:10.1358/ dot.1997.33.4.425052

114. Raskind MA, Peskind ER, Wessel T, Yuan W; The Galantamine USA-1 Study Group. Galantamine in [Alzheimer's disease]. A 6-month randomized, placebo-controlled trial with a 6-month extension. Neurology. 2000;54:2261-2268. doi:10.1212/ WNL.54.12.2261

115. Zhao Q, Brett M, Van ON, et al. Galantamine pharmacokinetics, safety, and tolerability profiles are similar in healthy Caucasian and Japanese subjects. J Clin Pharmacol. 2002;42(9):1002-1010. doi:10.1177/0091270002042009007

116. Tayeb HO, Yang HD, Price BH, Tarazi FI. Pharmacotherapies for Alzheimer's disease: beyond cholinesterase inhibitors. Pharmacol Ther. 2012;134(1):8-25.

117. Buckley JS, Salpeter SR. A Risk-Benefit Assessment of Dementia Medications: systematic Review of the Evidence. Drugs Aging. 2015;32(6):453-467. doi:10.1007/s40266-015-0266-9

118. O'Bryant SE, Humphreys JD, Smith GE, et al. Detecting dementia with the mini-mental state examination in highly educated individuals. Arch Neurol. 2008;65(7):963-967. doi:10.1001/ archneur.65.7.963

119. Doraiswamy PM, Kaiser L, Bieber F, et al. The Alzheimer's Disease Assessment Scale: evaluation of psychometric properties and patterns of cognitive decline in multicenter clinical trials of mild to moderate Alzheimer's disease. Alzheimer Dis Assoc Disord. 2001;15(4):174-183. doi:10.1097/00002093200110000-00003

120. Panisset M, Roudier M, Saxton J, et al. Severe impairment battery. A neuropsychological test for severely demented patients. Arch Neurol. 1994;51(1):41-45. doi:10.1001/ archneur.1994.00540130067012

121. Collin C, Wade DT, Davies S, Horne V. The Barthel ADL Index: a reliability study. Int Disabil Stud. 1988;10(2):61-63. doi:10.3109/09638288809164103
122. Wade DT, Collin C. The Barthel ADL Index: a standard measure of physical disability? Int Disabil Stud. 1988;10(2):64-67. doi:10.3109/09638288809164105

123. Lawton MP, Brody EM. Assessment of older people: self-maintaining and instrumental activities of daily living. Gerontologist. 1969;9(3):179-186. doi:10.1093/geront/ 9.3 Part 1.179

124. Cummings JL, Mega M, Gray K, et al. The Neuropsychiatric Inventory: comprehensive assessment of psychopathology in dementia. Neurology. 1994;44(12):2308-2314. doi:10.1212/ WNL.44.12.2308

125. Qaseem A, Snow V, Cross JT, et al. Current pharmacologic treatment of dementia: a clinical practice guideline from the American College of Physicians and the American Academy of Family Physicians. Ann Intern Med. 2008;148(5):370-378. doi:10.7326/0003-4819-148-5-200803040-00008

126. Santaguida PS, Raina P, Booker L, et al. Pharmacological treatment of dementia. Evid Rep Technol Assess (Summ). 2004;97:1-16.

127. Tricco AC, Ashoor HM, Soobiah C, et al. Comparative Effectiveness and Safety of Cognitive Enhancers for Treating Alzheimer's Disease: systematic Review and Network Metaanalysis. $J$ Am Geriatr Soc. 2018;66(1):170-178. doi:10.1111/jgs. 15069

128. Trinh NH, Hoblyn J, Mohanty S, et al. Efficacy of cholinesterase inhibitors in the treatment of neuropsychiatric symptoms and functional impairment in Alzheimer disease: a meta- analysis. JAMA. 2003;289(2):210-216. doi:10.1001/jama.289.2.210

129. Isik AT, Soysal P, Usarel C. Effects of Acetylcholinesterase Inhibitors on Balance and Gait Functions and Orthostatic Hypotension in Elderly Patients With Alzheimer Disease. Am $J$ Alzheimers Dis Other Demen. 2016;31(7):580-584. doi: $10.1177 / 1533317516666195$

130. Winblad B, Kilander L, Eriksson S, et al. Donepezil in patients with severe Alzheimer's disease: double-blind, parallel-group, placebo-controlled study. Lancet. 2006;367(9516):1057-1065. doi:10.1016/S0140-6736(06)68350-5

131. Froelich L, Andreasen N, Tsolaki M, et al. Long-term treatment of patients with Alzheimer's disease in primary and secondary care: results from an international survey. Curr Med Res Opin. 2009;25(12):3059-3068. doi:10.1185/03007990903396626

132. Lockhart IA, Mitchell SA, Kelly S. Safety and tolerability of donepezil, rivastigmine and galantamine for patients with Alzheimer's disease: systematic review of the "real-world" evidence. Dement Geriatr Cogn Disord. 2009;28:389-403. doi:10.1159/000255578

133. Hansen RA, Gartlehner G, Webb AP, Morgan LC, Moore CG, Jonas DE. Efficacy and safety of donepezil, galantamine, and rivastigmine for the treatment of Alzheimer's disease: a systematic review and meta-analysis. Clin Interv Aging. 2008;3:211-225.

134. Kröger E, Van Marum R, Souverein P, Carmichael PH, Egberts T. Treatment with rivastigmine or galantamine and risk of urinary incontinence: results from a Dutch database study. Pharmacoepidemiol Drug Saf. 2015;24:276-285. doi:10.1002/ pds. 3741

135. Colovic MB, Krstic DZ, Lazarevic-Pasti TD, Bondzic AM, Vasic VM. Acetylcholinesterase inhibitors: pharmacology and toxicology. Curr Neuropharmacol. 2013;11:315-335. doi:10.2174/1570159X11311030006

136. Galligan JJ, Burks TF. Cholinergic neurons mediate intestinal propulsion in the rat. J Pharm Exper Ther. 1986;238(2):594-598.

137. Lewin MJ. Cellular mechanisms and inhibitors of gastric acid secretion. Drugs Today (Barc). 1999;35(10):743-752. doi:10.1358/dot.1999.35.10.561693 
138. Full prescription information. Razadyne (galantamine). Available from: https://www.janssenmd.com/pdf/razadyne/PI-RazadyneRazadyneER.pdf. Assessed November 22, 2020.

139. Soysal P, Isik AT, Stubbs B, et al. Acetylcholinesterase inhibitors are associated with weight loss in older people with dementia: a systematic review and meta-analysis. $J$ Neurol Neurosurg Psychiatry. 2016;87(12):1368-1374. doi:10.1136/jnnp-2016-313660

140. Full prescription information. Aricept (donepezil). Available from: https:/www.labeling.pfizer.com/ShowLabeling.aspx?id= 510. Accessed November 22, 2020.

141. Full prescription information. Exelon (rivastigmine). Available from: https://www.pharma.us.novartis.com/product/pi/pdf/exelon. pdf. Accessed November 22, 2020.

142. Cutler NR, Anand R, Hartman RD, et al. Antiemetic therapy for Alzheimer's patients receiving the cholinesterase inhibitor SDZ ENA 713 [abstract]. Clin Pharmacol Ther. 1998;63(2):188.

143. Kistler PM, Sanders P, Fynn SP, et al. Electrophysiologic and electroanatomic changes in the human atrium associated with age. $J$ Am Coll Cardiol. 2004;44(1):109-116. doi:10.1016/j. jacc.2004.03.044

144. Jones SA, Lancaster MK, Boyett MR. Ageing-related changes of connexins and conduction within the sinoatrial node. J Physiol (Lond). 2004;560(Pt 2):429-437. doi:10.1113/ jphysiol.2004.072108

145. Jane Newby V, Anne Kenny R, McKeith IG. Donepezil and cardiac syncope: case report. Int J Geriatr Psychiatry. 2004;19 (11):1110-1112. doi:10.1002/gps.1183

146. Shahani L. Donepezil-associated sick sinus syndrome. J Neuropsychiatry Clin Neurosci. 2014;26(1):E5. doi:10.1176/ appi.neuropsych. 12110270

147. Park-Wyllie LY, Mamdani MM, Li P, Gill SS, Laupacis A, Juurlink DN. Cholinesterase inhibitors and hospitalization for bradycardia: a population-based study. PLoS Med. 2009;6(9): e1000157. doi:10.1371/journal.pmed.1000157

148. Tanaka A, Koga S, Hiramatsu Y. Donepezil-induced adverse side effects of cardiac rhythm: 2 cases report of atrioventricular block and Torsade de Pointes. Intern Med. 2009;48(14):1219-1223. doi:10.2169/internalmedicine.48.2181

149. Takaya T, Okamoto M, Yodoi K, et al. Torsades de Pointes with QT prolongation related to donepezil use. J Cardiol. 2009;54 (3):507-511. doi:10.1016/j.jjcc.2009.03.011

150. Hadano Y, Ogawa H, Wakeyama T, et al. Donepezil-induced torsades de pointes without QT prolongation. J Cardiol Cases. 2013;8(2):e69-e71. doi:10.1016/j.jccase.2013.05.004

151. Celik IE, Acar B, Çay S. An unusual cardiovascular adverse effect of donepezil. Intern Med J. 2015;45(8):877-878. doi:10.1111/imj.12827

152. Gill SS, Anderson GM, Fischer HD, et al. Syncope and its consequences in patients with dementia receiving cholinesterase inhibitors: a population-based cohort study. Arch Intern Med. 2009;169(9):867-873. doi:10.1001/archinternmed.2009.43

153. Kim DH, Brown RT, Ding EL, Kiel DP, Berry SD. Dementia medications and risk of falls, syncope, and related adverse events meta-analysis of randomized controlled trials. J Am Geriatr Soc. 2011;59(6):1019-1031. doi:10.1111/j.1532-5415.2011.03450.x

154. Hernandez RK, Farwell W, Cantor MD, Lawler EV. Cholinesterase inhibitors and hospitalizations for bradycardia. J Am Geriatr Soc. 2009;57:1997-2003. doi:10.1111/j.15325415.2009.02488.x

155. Isik AT, Yildiz GB, Bozoglu E, et al. Cardiac safety of donepezil in elderly patients with Alzheimer disease. Intern Med. 2012;51 (6):575-578. doi:10.2169/internalmedicine.51.6671

156. Isik AT, Soysal P, Yay A. Which rivastigmine formula is better for heart in elderly patients with Alzheimer's disease: oral or patch? Am J Alzheimers Dis Other Demen. 2014;29(8):735-738. doi:10.1177/1533317514536598
157. Isik AT, Bozoglu E, Yay A, et al. Which cholinesterase inhibitor is the safest for the heart elderly patients with Alzheimer's disease? Am J Alzheimers Dis Other Demen. 2012;27(3):171-174. doi:10.1177/1533317512442999

158. Isik AT, Soysal P, Stubbs B, et al. Cardiovascular Outcomes of Cholinesterase Inhibitors in Individuals with Dementia: a Meta-Analysis and Systematic Review. $J$ Am Geriatr Soc. 2018;66(9):1805-1811. doi:10.1111/jgs.15415

159. Rowland JP, Rigby J, Harper AC, et al. Cardiovascular monitoring with acetylcholinesterase inhibitors: a clinical protocol. $A d v$ Psychiatr Treat. 2007;13:178-184. doi:10.1192/apt. bp. 106.002725

160. Babic T, Zurak N. Convulsions induced by donepezil. J Neurol Neurosurg Psychiatry. 1999;66(3):410. doi:10.1136/jnnp.66.3.410

161. Shareef J, Joseph J, Adithi K. A single case report on hyponatremia seizure induced by acetylcholinesterase inhibitors. Int J Pharm Pharm Sci. 2017;9(7):165-166. doi:10.22159/ ijpps.2017v9i7.19057

162. Ross JS, Shua-Haim JR. Aricept-induced nightmares in Alzheimer's disease: 2 case reports. J Am Geriatr Soc. 1998;46 (1):119-120. doi:10.1111/j.1532-5415.1998.tb01033.x

163. Bouman WP, Pinner G. Violent behavior associated with donepezil. Am J Psychiatry. 1998;155(11):1626-1627. doi:10.1176/ajp.155.11.1626a

164. Yorston GA, Gray R. Hypnopompic hallucinations with donepezil. J Psychopharmacol. 2000;14(3):303-304. doi:10.1177/026988110001400315

165. Wong CW. Pharmacotherapy for Dementia: a Practical Approach to the Use of Cholinesterase Inhibitors and Memantine. Drugs Aging. 2016;33(7):451-460. doi:10.1007/s40266-016-0372-3

166. Hashimoto M, Imamura $T$, Tanimukai S, Kazui H, Mori E. Urinary incontinence: an unrecognised adverse effect with donepezil. Lancet. 2000;356(9229):568. doi:10.1016/S01406736(00)02588-5

167. Ale I, Lachapelle JM, Maibach HI. Skin tolerability associated with transdermal drug delivery systems: an overview. Adv Ther. 2009;26(10):920-935. doi:10.1007/s12325-009-0075-9

168. Wohlrab J, Kreft B, Tamke B. Skin tolerability of transdermal patches. Expert Opin Drug Deliv. 2011;8(7):939-948. doi:10.1517/17425247.2011.574689

169. Osada T, Watanabe N, Asano N, Adachi Y, Yamamura K. Adverse drug events affecting medication persistence with rivastigmine patch application. Patient Prefer Adherence. 2018;12:1247-1252. doi:10.2147/PPA.S166680

170. Zannas AS, Okuno Y, Doraiswamy PM. Cholinesterase inhibitors and Pisa syndrome: a pharmacovigilance study. Pharmacotherapy. 2014;34(3):272-278. doi:10.1002/phar.1359

171. Hsu CW, Lee Y, Lee CY, Lin PY. Reversible Pisa Syndrome Induced by Rivastigmine in a Patient With Early-Onset Alzheimer Disease. Clin Neuropharmacol. 2017;40(3):147-148. doi:10.1097/WNF.0000000000000215

172. Miyaoka T, Seno H, Yamamori C, et al. Pisa syndrome due to a cholinesterase inhibitor (donepezil): a case report. J Clin Psychiatry. 2001;62(7):573-574. doi:10.4088/JCP.v62n07d13

173. Fleet JL, McArthur E, Patel A, et al. Risk of rhabdomyolysis with donepezil compared with rivastigmine or galantamine: a population-based cohort study. CMAJ. 2019;191(37):e1018e1024. doi:10.1503/cmaj.190337

174. Health Canada. Summary Safety Review - ARICEPT (donepezil) - Risk of Rhabdomyolysis and Neuroleptic Malignant Syndrome [Internet]. Drug Heal Prod. 2015. Available from. http://www.hcsc.gc.ca/dhp-mps/medeff/reviews-examens/aricept-eng.php\#fnb1

175. Ekinci F, Soyaltin UE, Ugur MC, Develi A, Akar H. A rare case of Rhabdomyolysis probably due to donepezil. J Clin Case Rep. 2014;4:465. 
176. Verrico MM, Nace DA, Towers AL. Fulminant chemical hepatitis possibly associated with donepezil and sertraline therapy. $J \mathrm{Am}$ Geriatr Soc. 2000;48:1659-1663. doi:10.1111/j.1532-5415.2000. tb03879.x

177. Trenaman SC, Bowles SK, Kirkland S, et al. An examination of three prescribing cascades in a cohort of older adults with dementia. BMC Geriatr. 2021;21(1):297. doi:10.1186/s12877021-02246-2

178. Vouri SM, Possinger MC, Usmani S, et al. Evaluation of the Potential Acetylcholinesterase Inhibitor-Induced Rhinorrhea Prescribing Cascade. J Am Geriatr Soc. 2020;68(2):440-441. doi:10.1111/jgs. 16224

179. Gill SS, Mamdani M, Naglie G, et al. A prescribing cascade involving cholinesterase inhibitors and anticholinergic drugs. Arch Intern Med. 2005;165(7):808-813. doi:10.1001/ archinte.165.7.808

180. Bowie MW, Slattum PW. Pharmacodynamics in older adults: a review. Am $J$ Geriatr Pharmacother. 2007;5:263-303. doi:10.1016/j.amjopharm.2007.10.001

181. Maher D, Ailabouni N, Mangoni AA, Wiese MD, Reeve E. Alterations in drug disposition in older adults: a focus on geriatric syndromes. Expert Opin Drug Metab Toxicol. 2021;17(1):41-52. doi:10.1080/17425255.2021.1839413

182. Farrall AJ, Wardlaw JM. Blood-brain barrier: ageing and microvascular disease - systematic review and meta-analysis. Neurobiol Aging. 2009;30(3):337-352. doi:10.1016/j. neurobiolaging.2007.07.015

183. Nobili A, Garattini S, Mannucci PM. Multiple diseases and polypharmacy in the elderly: challenges for the internist of the third millennium. $J$ Comorbidity. 2011;1:28-44. doi:10.15256/ joc.2011.1.4

184. Onder G, Marengoni A, Russo P, et al. Advanced age and medication prescription: more years, less medications? A Nationwide report from the Italian Medicines Agency. $J \mathrm{Am}$ Med Dir Assoc. 2016;17(2):168-172. doi:10.1016/j. jamda.2015.08.009

185. Gustafsson M, Sjölander M, Pfister B, Jonsson J, Schneede J, Lövheim H. Drug-related hospital admissions among old people with dementia. Eur J Clin Pharmacol. 2016;72(9):1143-1153. doi:10.1007/s00228-016-2084-3

186. Pirmohamed M, James S, Meakin S, et al. Adverse drug reactions as cause of admission to hospital: prospective analysis of 18820 patients. BMJ. 2004;329(7456):15-19. doi:10.1136/ bmj.329.7456.15

187. Desai AK, Grossberg GT. Rivastigmine for Alzheimer's disease. Expert Rev Neurother. 2005;5(5):563-580. doi:10.1586/ 14737175.5.5.563

188. Desai AK, Grossberg GT. Review of rivastigmine and its clinical applications in Alzheimer's disease and related disorders. Expert Opin Pharmacother. 2001;2(4):653-666. doi:10.1517/ 14656566.2.4.653

189. Román GC, Rogers SJ. Donepezil: a clinical review of current and emerging indications. Expert Opin Pharmacother. 2004;5 (1):161-180. doi:10.1517/14656566.5.1.161

190. Kurz A, Farlow M, Lefèvre G. Pharmacokinetics of a novel transdermal rivastigmine patch for the treatment of Alzheimer's disease: a review. Int $J$ Clin Pract. 2009;63(5):799-805. doi:10.1111/j.1742-1241.2009.02052.x

191. Wysokiński A, Sobów T, Kłoszewska I, Kostka T. Mechanisms of the anorexia of aging-a review. Age (Dordr). 2015;37(4):9821. doi:10.1007/s11357-015-9821-x

192. Thompson CM, Johns DO, Sonawane B, et al. Database for physiologically based pharmacokinetic (PBPK) modeling: physiological data for healthy and health-impaired elderly. $J$ Toxicol Environ Health B Crit Rev. 2009;12(1):1-24. doi:10.1080/ 10937400802545060
193. Hughes VA, Frontera WR, Wood M, et al. Longitudinal muscle strength changes in older adults: influence of muscle mass, physical activity, and health. J Gerontol a Biol Sci Med Sci. 2001;56 (5):B209-217. doi:10.1093/gerona/56.5.B209

194. Hubbard RE, O'Mahony MS, Calver BL, Woodhouse KW. Nutrition, inflammation, and leptin levels in aging and frailty. $J$ Am Geriatr Soc. 2008;56(2):279-284. doi:10.1111/j.15325415.2007.01548.x

195. Reeve E, Wiese MD, Mangoni AA. Alterations in drug disposition in older adults. Expert Opin Drug Metab Toxicol. 2015;11 (4):491-508. doi:10.1517/17425255.2015.1004310

196. Le Couteur DG, Blyth FM, Creasey HM, et al. The association of alanine transaminase with aging, frailty, and mortality. J Gerontol a Biol Sci Med Sci. 2010;65(7):712-717. doi:10.1093/gerona/glq082

197. Dooley M, Lamb HM. Donepezil: a review of its use in Alzheimer's disease. Drugs Aging. 2000;16(3):199-226. doi:10.2165/00002512-200016030-00005

198. Hubbard RE, O'Mahony MS, Calver BL, Woodhouse KW. Plasma esterases and inflammation in ageing and frailty. Eur $J$ Clin Pharmacol. 2008;64(9):895-900. doi:10.1007/s00228008-0499-1

199. Renton KW. Regulation of drug metabolism and disposition during inflammation and infection. Expert Opin Drug Metab Toxicol. 2005;1(4):629-640. doi:10.1517/17425255.1.4.629

200. Aitken AE, Richardson TA, Morgan ET. Regulation of drug-metabolizing enzymes and transporters in inflammation. Anпи Rev Pharmacol Toxicol. 2006;46:123-149. doi:10.1146/ annurev.pharmtox.46.120604.141059

201. Wynne H. Drug metabolism and ageing. J Br Menopause Soc. 2005;11(2):51-56. doi:10.1258/136218005775544589

202. Zoli M, Magalotti D, Bianchi G, et al. Total and functional hepatic blood flow decrease in parallel with ageing. Age Ageing. 1999;28(1):29-33. doi:10.1093/ageing/28.1.29

203. Wynne HA, Cope LH, Mutch E, Rawlins MD, Woodhouse KW, James OFW. The effect of age upon liver volume and apparent liver blood flow in healthy man. Hepatology. 1989;9(2):297-301. doi:10.1002/hep.1840090222

204. Klotz U. Pharmacokinetics and drug metabolism in the elderly. Drug Metab Rev. 2009;41(2):67-76. doi:10.1080/ 03602530902722679

205. Butler JM, Begg EJ. Free drug metabolic clearance in elderly people. Clin Pharmacokinet. 2008;47(5):297-321. doi:10.2165/ 00003088-200847050-00002

206. Tiseo PJ, Vargas R, Perdomo CA, Friedhoff LT. An evaluation of the pharmacokinetics of donepezil $\mathrm{HCl}$ in patients with impaired hepatic function. Br J Clin Pharmacol. 1998;46 Suppl 1(Suppl 1):51-55. doi:10.1046/j.1365-2125.1998.0460s1051.x

207. Tiseo PJ, Foley K, Friedhoff LT. An evaluation of the pharmacokinetics of donepezil $\mathrm{HCl}$ in patients with moderately to severely impaired renal function. Br J Clin Pharmacol. 1998;46 Suppl 1 (Suppl1):56-60. doi:10.1046/j.1365-2125.1998.0460s1056.x

208. Fliser D, Zeier M, Nowack R, Ritz E. Renal functional reserve in healthy elderly subjects. $J$ Am Soc Nephrol. 1993;3 (7):1371-1377. doi:10.1681/ASN.V371371

209. Viallon A, Guyomarch P, Marjollet O, et al. Creatinine clearance and drug prescriptions for the elderly. A study of 419 patients older than 70 years admitted through the emergency department. Presse Med. 2006;35:413-417. doi:10.1016/S0755-4982(06) 74605-X

210. Farlow MR. Clinical pharmacokinetics of galantamine. Clin Pharmacokinet. 2003;42(15):1383-1392. doi:10.2165/00003088200342150-00005

211. Gottwald MD, Rozanski RI. Rivastigmine, a brain-region selective acetylcholinesterase inhibitor for treating Alzheimer's disease: review and current status. Expert Opin Investig Drugs. 1999;8(10):1673-1682. doi:10.1517/13543784.8.10.1673 
212. Hrycyna CA. Molecular genetic analysis and biochemical characterization of mammalian P- glycoproteins involved in multidrug resistance. Semin Cell Dev Biol. 2001;12(3):247-256. doi: $10.1006 / \mathrm{scdb} .2000 .0250$

213. Alavijeh MS, Chishty M, Qaiser MZ, Palmer AM. Drug metabolism and pharmacokinetics, the blood-brain barrier, and central nervous system drug discovery. NeuroRx. 2005;2(4):554-571. doi:10.1602/neurorx.2.4.554

214. van Waterschoot RA, Schinkel AH. A critical analysis of the interplay between cytochrome $\mathrm{P} 4503 \mathrm{~A}$ and P-glycoprotein: recent insights from knockout and transgenic mice. Pharmacol Rev. 2011;63(2):390-410. doi:10.1124/pr.110.002584

215. van Assema DM, Lubberink M, Rizzu P, et al. Blood-brain barrier P-glycoprotein function in healthy subjects and Alzheimer's disease patients: effect of polymorphisms in the ABCB1 gene. EJNMMI Res. 2012;2(1):57. doi:10.1186/2191-219X-2-57

216. Trifirò G, Spina E. Age-related changes in pharmacodynamics: focus on drugs acting on central nervous and cardiovascular systems. Curr Drug Metab. 2011;12(7):611-620. doi:10.2174/ 138920011796504473

217. Bishop JR. Pharmacogenetics. Handb Clin Neurol. 2018;147:59-73.

218. Noetzli M, Guidi M, Ebbing K, et al. Population pharmacokinetic approach to evaluate the effect of CYP2D6, CYP3A, ABCB1, POR and NR1I2 genotypes on donepezil clearance. $\mathrm{Br} J$ Clin Pharmacol. 2014;78(1):135-144. doi:10.1111/bcp.12325

219. Darvesh S, Hopkins DA, Geula C. Neurobiology of butyrylcholinesterase. Nat Rev Neurosci. 2003;4(2):131-138. doi:10.1038/nrn1035

220. Harold D, Macgregor S, Patterson CE, et al. A single nucleotide polymorphism in CHAT influences response to acetylcholinesterase inhibitors in Alzheimer's disease. Pharmacogenet Genomics. 2006;16(2):75-77. doi:10.1097/01.fpc.000018 9799.88596 .04

221. Pola R, Flex A, Ciaburri M, et al. Responsiveness to cholinesterase inhibitors in Alzheimer's disease: a possible role for the 192 Q/R polymorphism of the PON-1 gene. Neurosci Lett. 2005;382 (3):338-341. doi:10.1016/j.neulet.2005.03.027

222. Varsaldi F, Miglio G, Scordo MG, et al. Impact of the CYP2D6 polymorphism on steady-state plasma concentrations and clinical outcome of donepezil in Alzheimer's disease patients. Eur J Clin Pharmacol. 2006;62(9):721-726. doi:10.1007/s00228-006-0168-1

223. Pilotto A, Franceschi M, D'Onofrio G, et al. Effect of a CYP2D6 polymorphism on the efficacy of donepezil in patients with Alzheimer disease. Neurology. 2009;73(10):761-767. doi:10.1212/WNL.0b013e3181b6bbe3

224. Albani D, Martinelli Boneschi F. Replication study to confirm the role of CYP2D6 polymorphism rs1080985 on donepezil efficacy in Alzheimer's disease patients. J Alzheimers Dis. 2012;30 (4):745-749. doi:10.3233/JAD-2012-112123

225. Seripa D, Bizzarro A, Pilotto A, et al. Role of cytochrome P4502D6 functional polymorphisms in the efficacy of donepezil in patients with Alzheimer's disease. Pharmacogenet Genomics. 2011;21(4):225-230. doi:10.1097/FPC.0b013e32833f984c

226. Campbell NL, Skaar TC, Perkins AJ, et al. Characterization of hepatic enzyme activity in older adults with dementia: potential impact on personalizing pharmacotherapy. Clin Interv Aging. 2015;10:269-275. doi:10.2147/CIA.S65980

227. Cacabelos R, Martínez R, Fernández-Novoa L, et al. Genomics of Dementia: APOE- and CYP2D6-Related Pharmacogenetics. Int J Alzheimers Dis. 2012;2012:518901.

228. Liu M, Zhang Y, Huo YR, et al. Influence of the rs 1080985 Single Nucleotide Polymorphism of the CYP2D6 Gene and APOE Polymorphism on the Response to Donepezil Treatment in Patients with Alzheimer's Disease in China. Dement Geriatr Cogn Dis Extra. 2014;4(3):450-456. doi:10.1159/000367596
229. Choi SH, Kim SY, Na HR, et al. Effect of ApoE genotype on response to donepezil in patients with Alzheimer's disease. Dement Geriatr Cogn Disord. 2008;25(5):445-450. doi:10.1159/ 000124752

230. Cacabelos R. Influence of pharmacogenetic factors on Alzheimer's disease therapeutics. Neurodegener Dis. 2008;5(34):176-178. doi:10.1159/000113695

231. Zanger UM, Raimundo S, Eichelbaum M. Cytochrome P450 2D6: overview and update on pharmacology, genetics, biochemistry. Naunyn Schmiedebergs Arch Pharmacol. 2004;369(1):23-37. doi:10.1007/s00210-003-0832-2

232. Zhou SF. Polymorphism of human cytochrome P450 2D6 and its clinical significance: part I. Clin Pharmacokinet. 2009;48 (11):689-723.

233. Bradford LD. CYP2D6 allele frequency in European Caucasians, Asians, Africans and their descendants. Pharmacogenomics. 2002:3:229-243. doi:10.1517/14622416.3.2.229

234. Martinelli-Boneschi F, Giacalone G, Magnani G, et al. Pharmacogenomics in Alzheimer's disease: a genome-wide association study of response to cholinesterase inhibitors. Neurobiol Aging. 2013;34(6):1711.e7-13. doi:10.1016/j. neurobiolaging.2012.12.008

235. Lu J, Fu J, Zhong Y, et al. Association between ABCA1 gene polymorphisms and the therapeutic response to donepezil therapy in Han Chinese patients with Alzheimer's disease. Brain Res Bull. 2018;140:1-4. doi:10.1016/j.brainresbull.2018.03.014

236. Triplitt C. Drug interactions of medications commonly used in diabetes. Diabetes. 2006;19(4):202-211.

237. Tavassoli N, Sommet A, Lapeyre-Mestre M, Bagheri H, Montrastruc JL. Drug interactions with Cholinesterase inhibitors: an analysis of the French pharmacovigilance database and a comparison of two national drug formularies (Vidal, British National Formulary). Drug Saf. 2007;30(11):1063-1071. doi:10.2165/00002018-200730110-00005

238. Delafuente JC. Understanding and preventing drug interactions in elderly patients. Crit Rev Oncol Hematol. 2003;48(2):133-143. doi:10.1016/j.critrevonc.2003.04.004

239. Johnell K, Klarin I. The relationship between number of drugs and potential drug-drug interactions in the elderly: a study of over 600,000 elderly patients from the Swedish Prescribed Drug Register. Drug Saf. 2007;30(10):911-918. doi:10.2165/ 00002018-200730100-00009

240. Gallicano K, Drusano G. Introduction to drug interactions. In: Piscitelli SC, Rodvold K, editors. Drug Interactions in Infectious Diseases. 2nd ed. Totowa: Humana Press Inc; 2005:1-12.

241. Pasqualetti G, Tognini S, Calsolaro V, et al. Potential drug-drug interactions in Alzheimer patients with behavioral symptoms. Clin Interv Aging. 2015;10:1457-1466.

242. Magnuson TM, Keller BK, Burke WJ. Extrapyramidal side effects in a patient treated with risperidone plus donepezil. Am $J \quad$ Psychiatry. 1998;155(10):1458-1459. doi:10.1176/ ajp.155.10.1458a

243. Mehrpouya M, Ataei S, Nili-Ahmadabadi A. Potential drug interactions with cholinesterase inhibitors in Alzheimer patients: a guideline for Neurologists. J Appl Pharm Sci. 2017;7 (1):223-226. doi:10.7324/JAPS.2017.70134

244. Lin JH, Lu AYH. Inhibition and induction of cytochrome P450 and the clinical implications. Clin Pharmacokinet. 1998;35 (5):361-390. doi:10.2165/00003088-199835050-00003

245. McEneny-King A, Edginton AN, Pp R. Investigating the binding interactions of the anti- Alzheimer's drug donepezil with CYP3A4 and P-glycoprotein. Bioorg Med Chem Lett. 2015;25 (2):297-301. doi:10.1016/j.bmcl.2014.11.046

246. Spina E, Scordo MG, D'Arrigo C. Metabolic drug interactions with new psychotropic agents. Fundam Clin Pharmacol. 2003;17 (5):517-538. doi:10.1046/j.1472-8206.2003.00193.x 
247. Tiseo PJ, Perdomo CA, Friedhoff LT. Concurrent administration of donepezil $\mathrm{HCl}$ and ketoconazole: assessment of pharmacokinetic changes following single and multiple doses. $\mathrm{Br} J$ Clin Pharmacol. 1998;46(Suppl 1):30-34. doi:10.1046/j.13652125.1998.0460s1030.x

248. Defilippi JL, Crismon ML. Drug interactions with cholinesterase inhibitors. Drugs Aging. 2003;20(6):437-444. doi:10.2165/ 00002512-200320060-00003

249. Carrier L. Donepezil and paroxetine: possible drug interaction. $J$ Am Geriatr Soc. 1999;47(8):1037. doi:10.1111/j.15325415.1999.tb01306.x

250. Finch A, Pillans P. P-glycoprotein and its role in drug-drug interactions. Aust Prescr. 2014;37:137-139. doi:10.18773/ austprescr.2014.050

251. US Food and Drug Administration. Clinical drug interaction studies-Cytochrome P450 enzyme- and transporter-mediated drug interactions guidance for industry; January 2020. Available from: https://www.fda.gov/regulatory-information/search-fdaguidance-documents/clinical-drug-interaction-studies-cytochrome -p450-enzyme-and-transporter-mediated-drug-interactions. Accessed on November 5, 2020.

252. Takeuchi R, Shinozaki K, Nakanishi T, Tamai I. Local Drug-Drug Interaction of Donepezil with Cilostazol at Breast Cancer Resistance Protein (ABCG2) Increases Drug Accumulation in Heart. Drug Metab Dispos. 2016;44(1):68-74. doi:10.1124/dmd.115.066654

253. Johnell K, Fastbom J. Concurrent use of anticholinergic drugs and cholinesterase inhibitors: register-based study of over 700,000 elderly patients. Drugs Aging. 2008;25:871-877. doi:10.2165/ 00002512-200825100-00006

254. Modi A, Weiner M, Craig BA, Sands LP, Rosenman MB, Thomas J. Concomitant use of anticholinergics with acetylcholinesterase inhibitors in Medicaid recipients with dementia and residing in nursing homes. $J$ Am Geriatr Soc. 2009;57:1238-1244. doi:10.1111/j.1532-5415.2009.02258.x

255. Walker C, Perks D. Do you know about donepezil and succinylcholine? Anaesthesia. 2002;57:1041. doi:10.1046/ j.1365-2044.2002.00117.x

256. Sprung J, Castellani WJ, Srinivasan V, Udayashankar S. The effects of donepezil and neostigmine in a patient with unusual pseudocholinesterase activity. Anesth Analg. 1998;87(5):1203-1205.

257. Sánchez Morillo J, Demartini Ferrari A, Roca de Togores López A. Interacción entre donepezilo y bloqueantes musculares en la enfermedad de Alzheimer [Interaction of donepezil and muscular blockers in Alzheimer's disease]. Rev Esp Anestesiol Reanim. 2003;50(2):97-100.

258. Carcenac D, Martin-Hunyadi C, Kiesmann M, DemuynckRoegel C, Alt M, Kuntzmann F. Syndrome extrapyramidal sous donepezil [Extra-pyramidal syndrome induced by donepezil]. Presse Med. 2000;29(18):992-993.

259. Shimizu S, Mizuguchi Y, Sobue A, Fujiwara M, Morimoto T, Ohno Y. Interaction between anti- Alzheimer and antipsychotic drugs in modulating extrapyramidal motor disorders in mice. J Pharmacol Sci. 2015;127(4):439-445. doi:10.1016/j.jphs.2015.03.004

260. Bentue-Ferrer D, Tribut O, Polard E, Allain H. Clinically significant drug interactions with cholinesterase inhibitors: a guide for neurologists. CNS Drugs. 2003;17:947-963. doi:10.2165/ 00023210-200317130-00002

261. [No authors listed]. Bradycardia due to cholinesterase inhibitors: identify adverse effects and take them into account. Prescrire Int. 2011;20(115):95.

262. Hong YJ, Han HJ, Youn YC, et al. Safety and tolerability of donepezil $23 \mathrm{mg}$ with or without intermediate dose titration in patients with Alzheimer's disease taking donepezil $10 \mathrm{mg}$ : a multicenter, randomized, open-label, parallel-design, threearm, prospective trial. Alzheimers Res Ther. 2019;11(1):37. doi:10.1186/s13195-019-0492-1
263. Christensen DD. Higher-dose ( $23 \mathrm{mg} /$ day) donepezil formulation for the treatment of patients with moderate-to-severe Alzheimer's disease. Postgrad Med. 2012;124(6):110-116. doi:10.3810/ pgm.2012.11.2589

264. Reyes JF, Vargas R, Kumar D, et al. Steady-state pharmacokinetics, pharmacodynamics and tolerability of donepezil hydrochloride in hepatically impaired patients. Br J Clin Pharmacol. 2004;58(Suppl 1):9-17. doi:10.1111/j.1365-2125.2004.01802.x

265. Ali TB, Schleret TR, Reilly BM, et al. Adverse effects of cholinesterase inhibitors in dementia, according to the pharmacovigilance databases of the United-States and Canada. PLoS One. 2015;10(12):e0144337. doi:10.1371/journal.pone.0144337

266. Sheffrin M, Miao Y, Boscardin WJ, et al. Weight loss associated with cholinesterase inhibitors in individuals with dementia in a national healthcare system. $J$ Am Geriatr Soc. 2015;63 (8):1512-1518. doi:10.1111/jgs.13511

267. Vetrano DL, Tosato M, Colloca G, et al. Polypharmacy in nursing home residents with severe cognitive impairment: results from the SHELTER Study. Alzheimers Dement. 2013;9(5):587-593. doi:10.1016/j.jalz.2012.09.009

268. Renn BN, Asghar-Ali AA, Thielke S, et al. A Systematic Review of Practice Guidelines and Recommendations for Discontinuation of Cholinesterase Inhibitors in Dementia. Am $J$ Geriatr Psychiatry. 2018;26(2):134-147. doi:10.1016/j.jagp.2017.09.027

269. Reeve E, Farrell B, Thompson W, et al. Deprescribing cholinesterase inhibitors and memantine In dementia: guideline summary. Med J Aust. 2019;210(4):174-179. doi:10.5694/mja2.50015

270. Corsonello A, Pedone C, Incalzi RA. Age-related pharmacokinetic and pharmacodynamic changes and related risk of adverse drug reactions. Curr Med Chem. 2010;17(6):571-584. doi:10.2174/092986710790416326

271. Gurwitz JH, Field TS, Harrold LR, et al. Incidence and preventability of adverse drug events among older persons in the ambulatory setting. JAMA. 2003;289(9):1107-1116. doi:10.1001/jama.289.9.1107

272. Eshetie TC, Nguyen TA, Gillam MH, Kalisch Ellett LM. A narrative review of problems with medicines use in people with dementia. Expert Opin Drug Saf. 2018;17(8):825-836. doi:10.1080/14740338.2018.1497156

273. Pfister B, Jonsson J, Gustafsson M. Drug-related problems and medication reviews among old people with dementia. BMC Pharmacol Toxicol. 2017;18(1):52. doi:10.1186/s40360-017-0157-2

274. Wucherer D, Thyrian JR, Eichler T, et al. Drug-related problems in community-dwelling primary care patients screened positive for dementia. Int Psychogeriatrics. 2017;29(11):1857-1868. doi:10.1017/S1041610217001442

275. Mallet L, Spinewine A, Huang A. The challenge of managing drug interactions in elderly people. Lancet. 2007;370 (9582):185-191. doi:10.1016/S0140-6736(07)61092-7

276. Lau DT, Mercaldo ND, Harris AT, Trittschuh E, Shega J, Weintraub S. Polypharmacy and potentially inappropriate medication use among community-dwelling elders with dementia. Alzheimer Dis Assoc Disord. 2010;24(1):56-63. doi:10.1097/ WAD.0b013e31819d6ec9

277. Micromedex ${ }^{\circledR}$ HealthCare Series (internet database) Version 2.0. Greenwood Village, Colorado: Thomson Healthcare Inc; 2013. Available from: http://www.micromedexsolutions.com. Accessed November 22, 2020.

278. By the 2019 American Geriatrics Society Beers Criteria Update Expert Panel. American Geriatrics Society 2019 updated AGS Beers Criteria for potentially inappropriate medication use in older adults. J Am Geriatr Soc. 2019;67(4):674-694.

279. Gustafsson M, Sjölander M, Pfister B, Schneede J, Lövheim H. Effects of Pharmacists' Interventions on Inappropriate Drug Use and Drug-Related Readmissions in People with Dementia-A Secondary Analysis of a Randomized Controlled Trial. Pharmacy (Basel). 2018;6(1):7. doi:10.3390/pharmacy6010007 
280. Heikkilä T, Lekander T, Raunio H. Use of an online surveillance system for screening drug interactions in prescriptions in community pharmacies. Eur J Clin Pharmacol. 2006;62(8):661-665. doi:10.1007/s00228-006-0149-4

281. Horn JR, Hansten PD, Chan LN. Proposal for a new tool to evaluate drug interaction cases. Ann Pharmacother. 2007;41 (4):674-680. doi:10.1345/aph.1H423

282. Le Couteur DG, Robinson M, Leverton A, et al. Adherence, persistence and continuation with cholinesterase inhibitors in Alzheimer's disease. Australas J Ageing. 2012;31(3):164-169. doi:10.1111/j.1741-6612.2011.00564.x

283. Cotrell V, Wild K, Bader T. Medication management and adherence among cognitively impaired older adults. J Gerontol Soc Work. 2006;47(3-4):31-46. doi:10.1300/J083v47n03 03

284. Thiruchselvam T, Naglie G, Moineddin R, et al. Risk factors for medication nonadherence in older adults with cognitive impairment who live alone. Int $J$ Geriatr Psychiatry. 2012;27 (12):1275-1282. doi:10.1002/gps.3778
285. Maxwell CJ, Stock K, Seitz D, Herrmann N. Persistence and adherence with dementia pharmacotherapy: relevance of patient, provider, and system factors. Can J Psychiatry. 2014;59 (12):624-631. doi:10.1177/070674371405901203

286. Elliott RA, Goeman D, Beanland C, Koch S. Ability of older people with dementia or cognitive impairment to manage medicine regimens: a narrative review. Curr Clin Pharmacol. 2015;10 (3):213-221. doi:10.2174/1574884710666150812141525

287. Arlt S, Lindner R, Rösler A, von Renteln-kruse W. Adherence to medication in patients with dementia: predictors and strategies for improvement. Drugs Aging. 2008;25(12):1033-1047. doi:10.2165/0002512-200825120-00005

288. Kröger E, Tatar O, Vedel I, et al. Improving medication adherence among community-dwelling seniors with cognitive impairment: a systematic review of interventions. Int J Clin Pharm. 2017;39 (4):641-656. doi:10.1007/s11096-017-0487-6

\section{Publish your work in this journal}

Therapeutics and Clinical Risk Management is an international, peerreviewed journal of clinical therapeutics and risk management, focusing on concise rapid reporting of clinical studies in all therapeutic areas, outcomes, safety, and programs for the effective, safe, and sustained use of medicines. This journal is indexed on PubMed Central, CAS,
EMBase, Scopus and the Elsevier Bibliographic databases. The manuscript management system is completely online and includes a very quick and fair peer-review system, which is all easy to use. Visit http://www.dovepress.com/testimonials.php to read real quotes from published authors. 